\title{
TRPM2, a Susceptibility Gene for Bipolar Disorder, Regulates Glycogen Synthase Kinase-3 Activity in the Brain
}

\author{
Yongwoo Jang, ${ }^{1}$ Sung Hoon Lee, ${ }^{1}$ Byeongjun Lee, ${ }^{1}$ Seungmoon Jung, ${ }^{2}$ Arshi Khalid, ${ }^{2}$ Kunitoshi Uchida, ${ }^{3}$ \\ Makoto Tominaga, ${ }^{3}$ Daejong Jeon, ${ }^{2,4}$ and Uhtaek $\mathrm{Oh}^{1,5}$ \\ ${ }^{1}$ Sensory Research Center, Creative Research Initiatives, College of Pharmacy, Seoul National University, Seoul 151-742, Republic of Korea, ${ }^{2}$ Department of \\ Bio and Brain Engineering, Korea Advanced Institute of Science and Technology, Daejeon 305-701, Republic of Korea, ${ }^{3}$ Division of Cell Signaling, Okazaki \\ Institute for Integrative Bioscience, National Institute for Physiological Sciences, Okazaki 444-8787, Japan, ${ }^{4}$ Department of Neurology, Comprehensive \\ Epilepsy Center, Biomedical Research Institute, Seoul National University Hospital, Seoul 110-744, Republic of Korea, and 5 Institut Pasteur Korea, \\ Sungnam-Si, Gyunggi-Do 463-400, Republic of Korea
}

Bipolar disorder (BD) is a psychiatric disease that causes mood swings between manic and depressed states. Although genetic linkage studies have shown an association between $\mathrm{BD}$ and TRPM2, $\mathrm{a} \mathrm{Ca}^{2+}$-permeable cation channel, the nature of this association is unknown. Here, we show that D543E, a mutation of Trpm2 that is frequently found in BD patients, induces loss of function. Trpm2-deficient mice exhibited BD-related behavior such as increased anxiety and decreased social responses, along with disrupted EEG functional connectivity. Moreover, the administration of amphetamine in wild-type mice evoked a notable increase in open-field activity that was reversed by the administration of lithium. However, the anti-manic action of lithium was not observed in the Trpm $2^{-1-}$ mice. The brains of Trpm2 $2^{-1-}$ mice showed a marked increase in phosphorylated glycogen synthase kinase-3 (GSK-3), a key element in BD-like behavior and a target of lithium. In contrast, activation of TRPM2 induced the dephosphorylation of GSK-3 via calcineurin, a Ca ${ }^{2+}$-dependent phosphatase. Importantly, the overexpression of the D543E mutant failed to induce the dephosphorylation of GSK-3. Therefore, we conclude that the genetic dysfunction of Trpm2 causes uncontrolled phosphorylation of GSK-3, which may lead to the pathology of BD. Our findings explain the long-sought etiologic mechanism underlying the genetic link between Trpm2 mutation and BD.

Key words: bipolar disorder; calcineurin; glycogen synthase kinase-3; mutation; susceptibilty; TRPM2

\section{Significance Statement}

Bipolar disorder (BD) is a mental disorder that causes changes in mood and the etiology is still unknown. TRPM2 is highly associated with $\mathrm{BD}$; however, its involvement in the etiology of $\mathrm{BD}$ is still unknown. We show here that TRPM2 plays a central role in causing the pathology of $\mathrm{BD}$. We found that D543E, a mutation of Trpm2 frequently found in BD patients, induces the loss of function. Trpm2-deficient mice exhibited mood disturbances and impairments in social cognition. TRPM2 actively regulates the phosphorylation of GSK-3, which is a main target of lithium, a primary medicine for treating BD. Therefore, abnormal regulation of GSK-3 by hypoactive TRPM2 mutants accounts for the pathology of BD, providing the possible link between BD and TRPM2.

\section{Introduction}

Bipolar disorder (BD) is a common yet severe mood disorder characterized by manic and depressive episodes. Individuals with

Received Dec. 26, 2014; revised July 3, 2015; accepted July 10, 2015.

Author contributions: D.J. and U.O. designed research; Y.J., S.H.L., B.L., S.J., A.K., K.U., M.T., and D.J. performed research; U.0. analyzed data; D.J. and U.0. wrote the paper.

This work was supported by the National Research Foundation of Korea (Grants NRF-2011-0018358, NRF2013R1A1A2063015, and NRF-2014R1A2A2A01002608), which is funded by the Ministry of Science, ICT and Future Planning, the BK21 + Program of Ministry of Education of Korea, and the Ministry of Health and Welfare (Korea Health 21 R\&D Grant HI12C0035 to D.J.)

Correspondence should be addressed to either of the following: Uhtaek Oh, Sensory Research Center, Creative Research Initiatives, College of Pharmacy, Seoul National University, Seoul 151-742, Republic of Korea, E-mail: utoh@snu.ac.kr; or Daejong Jeon, Department of Neurology, Comprehensive Epilepsy Center, Biomedical Research Institute, Seoul National University Hospital, Seoul 110-744, Republic of Korea, E-mail: clark.jeon@gmail.com.
BD suffer from life-long mood variations that may occur many times in a single day and can last for months (Belmaker and Bersudsky, 2004). During the manic stage, patients experience euphoria, aggressiveness, racing thoughts, talkativeness, impaired judgment, and sleep loss (Maytal et al., 2007; Goldberg et al., 2009; Ballester et al., 2014), whereas the depressive stage is associated with despair, reduced appetite, cognitive impairment, sleep disturbance, and often suicidal thoughts (Torrent et al., 2012; Undurraga et al., 2012; Walz et al., 2013). Therefore, BD patients tend to have high rates of suicide, divorce, unemploy-

Y. Jang's present address is McLean Hospital, Harvard Medical School, Belmont, MA 02478.

DOI:10.1523/JNEUROSCI.5251-14.2015

Copyright $\odot 2015$ the authors $\quad 0270-6474 / 15 / 3511811-13 \$ 15.00 / 0$ 
ment, and crime associated with the loss of social cognition (Leahy, 2007; Cusi et al., 2012).

The psychosocial environment during childhood plays a significant role in the etiology of BD (Leverich et al., 2002). Efforts to achieve personal goals may also evoke manic symptoms (Johnson et al., 2000). Genetic factors are also known to contribute to BD. Analyses of links among BD families have revealed that the chromosomal region $21 \mathrm{q} 22.3$ is a susceptibility locus (Straub et al., 1994). This region contains the Trpm2 gene (Nagamine et al., 1998). TRPM2 is a $\mathrm{Ca}^{2+}$-permeable cation channel that is strongly expressed in the brain, especially in the frontal cortex and other major nuclei associated with BD (Nagamine et al., 1998). Comparative analyses of the genomic DNA of BD patients have found an association between Trpm2 and BD (Kostyrko et al., 2006; McQuillin et al., 2006; Xu et al., 2009). Fine mapping of the 21q22.3 locus revealed two changed amino acids in the Trpm2 sequence: D543E in exon 11 and R755C in exon 15 (McQuillin et al., 2006). Kostyrko et al. (2006) detected seven genetic transitions (four exons, three introns) in Trpm2. A family-based association study further confirmed the association between D543E transition in exon 11 (SNP rs1556314) of Trpm2 and type-1 BD (Xu et al., 2009). TRPM2 is a $\mathrm{Ca}^{2+}$-permeable, nonselective channel that is activated by adenosine diphosphate ribose (ADPR), hydrogen peroxide, and other reactive oxygen species (Kühn et al., 2005). Therefore, TRPM2 has been described as a redox sensor in brain. Altered oxidative stress was reported in the postmortem prefrontal cortex and peripheral blood cells from BD patients (Andreazza et al., 2013; Gubert et al., 2013). In addition, the mood stabilizer lithium $\left(\mathrm{Li}^{+}\right)$, the first choice of drug for treating $\mathrm{BD}$, is capable of protecting against oxidative stress (Frey et al., 2006; Young and Newham, 2006). Therefore, a change in sensing oxidative stress such as in Trpm2 mutation can lead to mental disorders such as $\mathrm{BD} . \mathrm{Li}^{+}$is known to directly and/or indirectly inhibit the activity of glycogen synthase kinase-3 (GSK-3; Stambolic et al., 1996; Ryves and Harwood, 2001), which implies that abnormal GSK-3 activity is closely related to BD. Indeed, augmented GSK-3 activity leads to hyperactive behavior similar to mania in humans, whereas genetic ablation of GSK-3 elicits abnormal depressive behavior, including decreased exploratory activity, reduced aggression, and loss of social interaction (O'Brien et al., 2004; Kaidanovich-Beilin et al., 2009). Therefore, despite the lack of a direct link, changes in GSK-3 activity in the brain appear to play an important role in the psychopathology of BD.

Despite the numerous studies that have reported an association between TRPM 2 mutations and BD, the functional activities of Trpm2 mutants and etiologic insights into their association with $\mathrm{BD}$ are unknown. Therefore, we first performed functional studies on TRPM2 variants to determine how changes in TRPM2 activity affect GSK-3 activity. These findings may provide insight into the pathophysiological mechanisms of human BD.

\section{Materials and Methods}

\section{Current recording}

Whole-cell voltage-clamp recordings were performed at room temperature $\left(\sim 20-25^{\circ} \mathrm{C}\right)$ with a holding potential of $-60 \mathrm{mV}$ using an Axopatch 200B amplifier (Molecular Devices) and digitized using Digidata 1440 (Molecular Devices). Patch electrodes were constructed from borosilicate glass (PG52151-4; World Precision Instruments) using a P-97 Flaming/Brown Micropipette Puller (Sutter Instrument). The resistance of the glass pipettes was $2-3 \mathrm{M} \Omega$. To record the ADPR-induced current, the electrodes were filled with an intracellular solution containing the following (in mM): $118.5 \mathrm{KCl}, 2 \mathrm{MgCl}_{2}$, $\mathrm{KOH} 11.5$, EGTA 5, HEPES 10, 2 Mg-ATP, $0.2 \mathrm{Na}$-GTP, and $500 \mu \mathrm{M}$ ADPR, pH 7.2, adjusted with KOH.
The extracellular solution contained the following (in mM): $130 \mathrm{NaCl}, 2$ $\mathrm{MgCl}_{2}, 5 \mathrm{KCl}, 1 \mathrm{CaCl}_{2}, 10 \mathrm{HEPES}, \mathrm{pH}$ 7.2, adjusted with $\mathrm{HCl}$. Traces were acquired at $200 \mathrm{~Hz}$ and the data were analyzed using pClamp software (version 6.0; Molecular Devices).

\section{Calcium imaging}

Neuro-2a cells were grown on chamber slides (Nunc) in DMEM supplemented with $10 \%$ fetal bovine serum. After being left overnight, the cells were loaded with Fluo-3 AM (5 $\mu \mathrm{M}$; Invitrogen) containing $0.1 \%$ Pluronic F-127 (Invitrogen). To measure the time courses of $\left[\mathrm{Ca}^{2+}\right]_{i}$, the intensities of the fluorescent images of cells at $488 \mathrm{~nm}$ were measured every $3 \mathrm{~s}$ using a fluorescence microscope (Nikon). Twenty-four hours after transfection with vector and human TRPM2, basal $\left[\mathrm{Ca}^{2+}\right]_{\mathrm{i}}$ levels were determined by measuring the fluorescent intensities at $488 \mathrm{~nm}$ after incubating the cells with Fluo-3 AM for $40 \mathrm{~min}$.

\section{Animals}

The generation of TRPM2-deficient mice was described previously (Yamamoto et al., 2008). TRPM2-heterozygous (Trpm $2^{+/-}$) mice were backcrossed into a C57BL/6J inbred background over 10 generations. Male TRPM2 wild-type (WT; Trpm $2^{+/+}$) and TRPM2-deficient $\left(\operatorname{Trpm} 2^{-1^{-}}\right)$mice with a C57BL/6J background were used for analysis. All experiments were performed on 8- to 12-week-old male mice. Animals were maintained with ad libitum access to food and water under a 12:12 h light:dark cycle. Animal care and handling were performed according to the guidelines issued by the Institutional Animal Care and the Animal Use Committee at Seoul National University and the Korea Advanced Institute of Science and Technology.

\section{Behavioral tasks}

All behavioral procedures were video-recorded and the recorded data were analyzed by an experimenter unaware of the genotypes. There was no experimenter in the room during the behavior tasks.

Elevated plus maze. For the assessment of anxiety, elevated plus maze was performed as described previously (Jeon et al., 2010; Jung et al., 2013). The maze was made of plastic and consisted of 2 white, open arms $(25 \times 8 \mathrm{~cm}) ; 2$ black, enclosed arms $(25 \times 8 \times 20 \mathrm{~cm})$; and a central platform $(8 \times 8 \times 8 \mathrm{~cm})$ in the form of a cross. The maze was placed 50 $\mathrm{cm}$ above the floor. Mice were individually placed in the center with their heads directed toward one of the closed arms and recorded with a video camera. The total time spent in each arm or in the center and the total number of entries into each arm was analyzed by video monitoring for 5 min. Only when all four paws crossed from the center into an arm was this counted as an arm entry and used for measuring the amount of time spent in each arm.

Light/dark transition. For the assessment of anxiety, a light/dark transition task was performed as described previously (Takao and Miyakawa, 2006; Jeon et al., 2010). A light/dark box $(30 \times 45 \times 27 \mathrm{~cm})$ made of plastic comprised a dark compartment (one third of the total area) and a light compartment with a hole in the middle. The light compartment was illuminated at 400 lux. The elapsed time to entry into the light compartment (latency) and the amount of time (duration) spent in each compartment were measured over a $5 \mathrm{~min}$ period by video monitoring.

Social investigation of an anesthetized mouse target. The experiment was performed as described previously (Nicot et al., 2004). Naive male WT mice $(18-20 \mathrm{~g})$ were used as the target. They were anesthetized with 2,2,2 tribromoethanol $(0.2 \mathrm{ml} / 10 \mathrm{~g}$ of a $20 \mathrm{mg} / \mathrm{ml}$ solution, i.p. $) 15 \mathrm{~min}$ before presentation and then placed in the center of a clean cage $(40 \times 25 \times 18$ $\mathrm{cm}$ ) on a $3 \mathrm{~cm}$ sawdust layer. The subject mice (WT and $\operatorname{Trpm} 2^{-1^{-}}$) were introduced individually into the cage facing a corner and their behavior toward the target mouse was video-recorded for $5 \mathrm{~min}$. The duration and number of contacts (sniffing, touching, and climbing) were measured for $5 \mathrm{~min}$. A mouse was considered to be sniffing the anesthetized mouse when its head was facing the anesthetized mouse within 1 inch. The cage, target mouse, and sawdust were changed for every subject mouse.

Social interaction with a juvenile mouse. Male juvenile mice were used instead of adults to exclude any effect of mutual aggression (Moretti et al., 2005). A single mouse (male subject, WT and $\operatorname{Trpm} 2^{-1-}$ ) was allowed to roam freely in a new cage for $10 \mathrm{~min}$ (habituation). The cages 
used were identical to those in which the mice were normally housed. A novel juvenile (3-4 weeks old) male WT mouse was introduced to the cage and then allowed to roam freely for $5 \mathrm{~min}$ (test session). The following types of behavior were scored as social interaction: nose-to-nose sniffing, direct contact (pushing the snout or head underneath and crawling over or under the juvenile's body), and following closely (within $<1 \mathrm{~cm}$ ) (Silverman et al., 2010). The total time spent engaging in social interaction behavior was quantified.

Resident-intruder test. Resident mice were housed in isolation for $7 \mathrm{~d}$ without a change of bedding before testing. The isolation-induced resident-intruder aggression test was performed by introducing intruder mice into the home cages of resident mice. WT and Trpm $2^{-1-}$ mice were used as resident mice and naive male WT mice were used as intruder mice. Offensive behavior was measured by determining the latency to the first attack and the total number of bite attacks by the isolated resident mouse for $15 \mathrm{~min}$. If an animal did not make a bite attack, the latency to the first attack was recorded as $900 \mathrm{~s}$ (test duration) and all of the other attack scores were recorded as zero.

Sociability/social novelty preference test. This experiment was based on a previously described protocol (Moy et al., 2004; Nadler et al., 2004). The apparatus for this experiment was a black Plexiglas rectangular box with three chambers $(60 \times 30 \times 22 \mathrm{~cm})$. The middle chamber $(17 \times 30 \times$ $22 \mathrm{~cm}$ ) was slightly smaller than the side chambers (each $21.5 \times 30 \times 22$ $\mathrm{cm})$. Dividing partitions were made from clear Plexiglas, with small doorways $(5 \times 8 \mathrm{~cm})$ allowing access to each chamber. Inverted wire cages (wire cups: diameter, $7.7 \mathrm{~cm}$; height, $10 \mathrm{~cm}$ ) were placed in each side chamber to house the stranger. The stranger was placed on the left/right (counterbalanced) side. For habituation, the subject mice (WT and $\operatorname{Trpm} 2^{-1^{-}}$) were first placed in the middle chamber and allowed to explore for $10 \mathrm{~min}$. During habituation, each of the two side chambers contained an empty wire cage. In the subsequent sociability test, a novel mouse (Stranger 1, age-matched male WT mouse) was enclosed in a wire cage and placed in one of the side chambers; the subject mice were then allowed to explore for $10 \mathrm{~min}$. Social novelty preference test was performed immediately after the sociability test. Another novel mouse (Stranger 2, age-matched male WT mouse) was enclosed in the other wire cage and the subject mice were allowed to explore the two strangers for $10 \mathrm{~min}$. In sociability and social novelty preference tests, the time spent sniffing each wire cage and in each of the side chambers was measured. A mouse was considered to be sniffing the wire cage when its head was facing the cage from a distance of within 1 inch. An entry was only counted when all four paws crossed from the middle chamber into a side chamber.

Open-field activity. To assess locomotor activity, the open-field task was performed as described previously (Cho et al., 2013). Individual mice were placed in a $37 \times 37 \mathrm{~cm}$ activity cage for $50 \mathrm{~min}$ and movements were recorded using the Auto-Track system (Columbus Instruments). The animal location, movements, and beam breaks were monitored in the horizontal and vertical planes of optical tracking frame. Total distance indicates the movement during $50 \mathrm{~min}$ in the activity cage.

AMP-induced hyperactivity. WT C57BL/6 and TRPM2-deficient mice (7 weeks old) were administered with saline or lithium ( $150 \mathrm{mg} / \mathrm{kg}$, i.p.) daily for $4 \mathrm{~d}$. On day 5 , saline or lithium $\left(\mathrm{Li}^{+}\right)$was administered by intraperitoneal injection, followed by amphetamine $(4 \mathrm{mg} / \mathrm{kg})$ or metamphetamine $(3 \mathrm{mg} / \mathrm{kg})$ administration $15 \mathrm{~min}$ later. The mice were placed individually in an activity cage immediately after the amphetamine (or met-amphetamine) was administered. The movements were recorded using the Auto-Track system. The dose of amphetamine and $\mathrm{Li}^{+}$was determined by a method described previously (Gould et al., 2007).

\section{Measurement of EEG}

Mice were subjected to EEG surgery 2 weeks before the recording of EEG signals, as described previously (Jeon et al., 2010; Jung et al., 2013). Mice were anesthetized with an intraperitoneal injection of $1 \%$ ketamine (30 $\mathrm{mg} / \mathrm{kg}$ ) and xylazine hydrochloride $(4 \mathrm{mg} / \mathrm{kg})$. Surgery was performed using a stereotaxic apparatus (Kopf Instruments). EEG recordings were obtained using tungsten electrodes $(0.005 \mathrm{inch}, 2 \mathrm{M} \Omega$ ) positioned in the prefrontal cortex (AP $2.0 \mathrm{~mm}$, L $0.2 \mathrm{~mm}$, and DV $1.5 \mathrm{~mm}$ from the bregma) and the parietal cortex (AP $-2.0 \mathrm{~mm}, \mathrm{~L} 2.5 \mathrm{~mm}$, and DV 0.8 $\mathrm{mm}$ from the bregma) with grounding over the cerebellum. Electrodes were fixed to the skull using dental acrylic. Electrical activities were recorded after being amplified $(\times 1200)$, band-pass filtered at $0.1-70 \mathrm{~Hz}$, and digitized at a sampling rate of $400 \mathrm{~Hz}$ using a digital EEG system (Comet XL; Astro-Med). Video and EEG signals were recorded continuously $24 \mathrm{~h}$ per day for $10 \mathrm{~d}$. The sample entropy, cross-correlation, and coherence of the EEG signals were analyzed offline using MATLAB, PSG Twin 4.2 (Astro-Med) and pClampfit 10.2 (Molecular Devices).

Sample entropy. Conceptually, sample entropy is based on the conditional probability that two sequences of " $m+1$ " length randomly selected from a signal will match, given that they match for the first " $m$ " elements of the sequences. Here, "match" means that the distance between the sequences is less than some criterion " $r$." Distance is measured in a vector sense. The conditional probability is estimated as the ratio of the unconditional probabilities of the matching sequences for lengths " $m$ +1 " and " $m$," and SaEn is calculated as the negative logarithm of this conditional probability (Richman and Moorman, 2000). Therefore, SaEn is defined as follows:

$$
\operatorname{SaEn}(m, r, N)=-\ln \left[A^{m}(r) / B^{m}(r)\right]
$$

where $B^{m}(r)$ is the estimated probability that two sequences match for $m$ points and $A^{m}(r)$ is the estimated probability that the sequences match for $m+1$ points. $A^{m}(r)$ and $B^{m}(r)$ are evaluated from the data using a relative frequency approach. SaEn is calculated using $m=2$ and $r=20 \%$ of the SD of the $30 \mathrm{~s}$ data sequence. Defining $r$ as a fraction of the SD eliminates the dependence of SaEn on the signal amplitude.

Cross $=$ correlation . The cross-correlation function is perhaps the most widely used measure of interdependence between signals in neuroscience. Let us suppose we have two simultaneously measured discrete time series, $x_{\mathrm{n}}$ and $y_{\mathrm{n}}, n=1 \ldots \mathrm{N}$. The cross-correlation function is defined as follows:

$$
c_{x y}(\tau)=\frac{1}{N-\tau} \sum_{i=1}^{N-\tau}\left(\frac{x_{i}-\bar{x}}{\sigma_{x}}\right)\left(\frac{y_{i+\tau}-\bar{y}}{\sigma_{y}}\right)
$$

Where $\bar{x}$ and $\sigma_{\mathrm{x}}$ denote the mean and variance and $\tau$ is the time lag. The cross-correlation function is basically the inner product between two normalized signals and it provides a measure of synchronization between them as a function of time lag. Its value ranges from -1 in the case of a completely inverse correlation to +1 for a complete correlation.

Coherence. The coherence function estimates the linear correlation between two signals as a function of the frequency. Coherence is sensitive to the interdependences that may be present in a limited frequency range and is formulated as the normalized amplitude of an estimated crossspectrum of signals, mathematically defined as follows:

$$
\Gamma_{x y}(\omega)=\frac{\left|\left\langle C_{x y}(\omega)\right\rangle\right|}{\sqrt{\left\langle C_{x x}(\omega)\right\rangle} \sqrt{C_{x x}(\omega)}}
$$

\section{Western blot analysis}

Protein lysates from the frontal cortices of WT and Trpm $2^{-1-}$ mice were prepared in RIPA cell lysis buffer (GenDEPOT) containing a protease inhibitor mixture (Roche). The lysates so obtained were subjected to an $8 \%$ SDS-PAGE gel. Proteins were transferred to PDVF membranes, which were then treated for $1 \mathrm{~h}$ with a TBS-T solution $(20 \mathrm{~mm}$ Tris/ $\mathrm{HCl}$, $500 \mathrm{~mm} \mathrm{NaCl}, 0.1 \%$ Tween 20 ) containing 2-5\% skimmed milk powder and incubated with primary antibodies against $\alpha$-tubulin (Millipore), GSK-3 $\alpha$ (Cell Signaling Technology), phospho (Ser21)-GSK-3 $\alpha$ (Cell Signaling Technology), GSK-3 $\beta$ (Cell Signaling Technology), and phospho (Ser9)-GSK-3 $\beta$ (Cell Signaling Technology) antibody overnight at $4^{\circ} \mathrm{C}$ on a rotary shaker. The PDVF membranes were washed 3 times in TBS-T solution, incubated with secondary antibody for $1 \mathrm{~h}$, and treated with WEST-ZOL ECL solution (iNtRON Biotech). Blots were analyzed using ImageQuant LAS 4000 chemiluminescence (GE Healthcare). The intensity of blots was calculated using ImageJ software. The calculated values were first divided by each $\alpha$-tubulin value. To quantify the phosphorylation of protein, the value of phosphorylated protein was again divided by each value of total protein. 
A

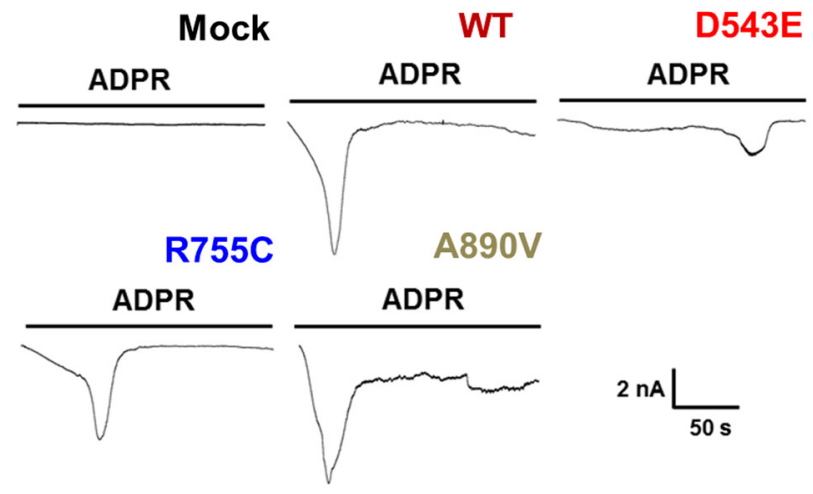

C

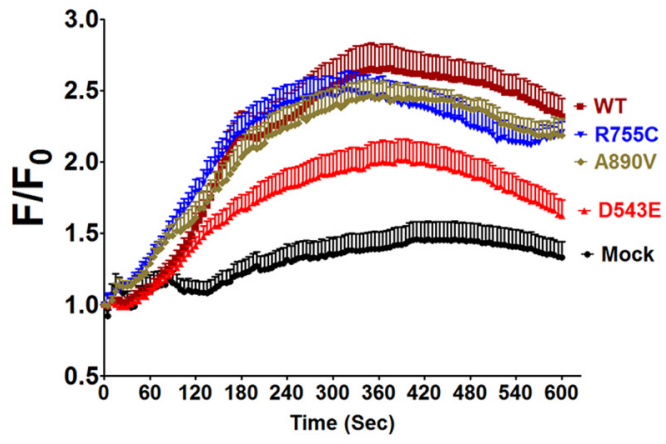

B

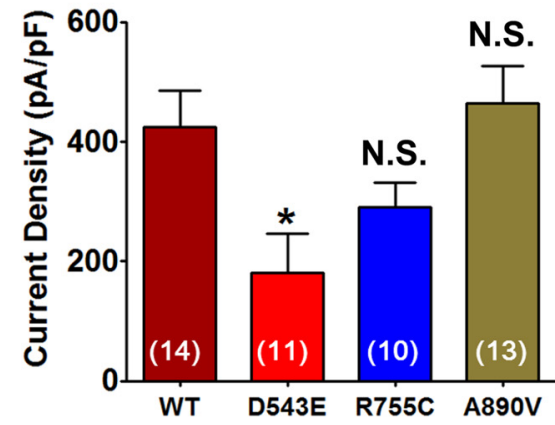

D

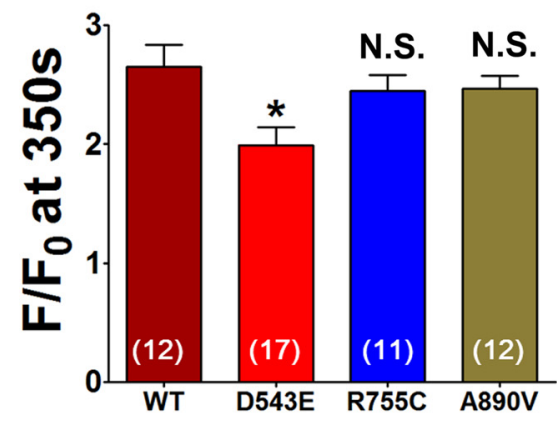

Figure 1. A D543E mutant of TRPM2 shows the loss-of-function activity. $A$, Current traces of HEK cells transfected with mock (empty vector), WT TRPM2, or D543E, R755C, and A890V mutants of TRPM2, activated by the pipette application of $500 \mu \mathrm{M}$ ADPR. B, Summary of the current densities activated by the ADPR of cells expressing WT TRPM2 or D543E, R755C, and A890V mutants of TRPM2. Numbers in parentheses represent the number of experiments. ${ }^{*} p<0.05$ (N.S., not significant), one-way ANOVA, Tukey's post hoc test. C, Ca ${ }^{2+}$-imaging traces of HEK cells transfected with mock, WT TRPM2, or D543E, R755C, and A890V mutants of TRPM2 after the application of $200 \mu \mathrm{M} \mathrm{H}_{2} \mathrm{O}_{2}$. D, Summary of the current densities of cells expressing WT TRPM2 or D543E, R755C, and A890V mutants of TRPM2. ${ }^{*} p<0.05$ (N.S., not significant), one-way ANOVA, Tukey's post hoc test.

\section{Statistics}

All results are shown as means \pm SEM. Student's $t$ test was used to determine statistical differences between two means. One-way ANOVA was used to conduct multiple comparisons of means, followed by the Tukey's post hoc test. Statistical significance was accepted for $p$ values of ${ }^{\star}<0.05,{ }^{* *}<0.01$, and ${ }^{* *}<0.001$, as indicated in the figures.

\section{Results}

A D543E mutant in the TRPM2 gene retains a loss of function in activity

We first performed functional tests on WT and TRPM2 mutants D543E, R755C, and A890V, which are reported in BD patients (Kostyrko et al., 2006; McQuillin et al., 2006; Xu et al., 2009). Because ADPR is a primary endogenous activator of TRPM2, current responses to $500 \mu \mathrm{M}$ ADPR in the pipette were tested on Neuro2a cells, a neuroblastoma cell line (Riboni et al., 1995) transfected with WT Trpm2, and its D543E, R755C, and A890V mutants. As shown in Figure $1 A, 500 \mu \mathrm{M}$ ADPR in the pipette evoked the abrupt activation of a robust current, followed by rapid inactivation in all 14 cells tested, with an average current density of $424.2 \pm 61.3 \mathrm{pA} / \mathrm{pF}$. In contrast, the D543E mutant elicited a markedly reduced current density in response to ADPR $\left(F_{(3,44)}=4.5,{ }^{\star} p<0.05\right.$ vs WT, one-way ANOVA, Tukey's post hoc test). The R755C and A890V mutants showed no appreciable difference in current density from that of the WT TRPM2 $(\mathrm{R} 755 \mathrm{C} ; 290.3 \pm 41.3 \mathrm{pA} / \mathrm{pF}, \mathrm{A} 890 \mathrm{~V} ; 463.6 \pm 68.6 \mathrm{pA} / \mathrm{pF}$, oneway ANOVA, Tukey's post hoc test; Fig. 1B).

The functional activities of these mutants were also tested with hydrogen peroxide, another activator of TRPM2, using $\mathrm{Ca}^{2+}$ sensitive fluorescence, Fluo-3 AM (Kühn et al., 2005). The appli- cation of $200 \mu \mathrm{M} \mathrm{H} \mathrm{H}_{2} \mathrm{O}_{2}$ in human embryonic kidney 293T (HEK293T) cells transfected with WT Trpm2 evoked $\mathrm{Ca}^{2+}$ sensitive fluorescence signals (Fig. $1 C$ ). The application of $\mathrm{H}_{2} \mathrm{O}_{2}$ in cells transfected with the D543E mutant evoked a significantly reduced $\left(F_{(3,48)}=4.1,{ }^{*} p<0.05\right.$ vs WT, one-way ANOVA) $\mathrm{Ca}^{2+}$ signal, whereas the Neuro-2a cells transfected with the R755C and $\mathrm{A} 890 \mathrm{~V}$ mutants responded to the $\mathrm{H}_{2} \mathrm{O}_{2}$ application in much the same way as the control cells transfected with WT Trpm2 (Fig. $1 C, D)$. These results suggest that a D543E transition to Trpm2 causes a loss of function in TRPM2 activity.

Changes in anxiety and social behaviors in $\operatorname{Trpm} 2^{-1-}$ mice Because BD-associated mutants tend to elicit loss of function, we investigated whether the TRPM2-deficient mice mimicked BDrelated behavior. BD is largely manifested in impairments of mood and social behavior (Belmaker and Bersudsky, 2004). We therefore gave the Trpm $2^{-1-}$ mice anxiety- and depressionrelated behavioral and social tasks to perform. To assess innate anxiety, the elevated plus maze (Fig. $2 A$ ) and light/dark transition (Fig. 2B) tasks were conducted. The Trpm $2^{-1-}$ mice spent less time $(20.0 \pm 2.4 \mathrm{~s}, n=10)$ in the open arms than the WT mice $\left(t_{(18)}=3.1, p<0.05\right)$, with no significant difference in the number of crossings between the two genotypes (Fig. $2 A$ ), suggesting an increase in anxiety in the Trpm $2^{-/-}$mice. In the light/dark transition task, the Trpm $2^{-1-}$ mice displayed a longer latency $(118.6 \pm 31.6 \mathrm{~s})$ to the light chamber compared with that of WT mice $\left(48.17 \pm 4.73 \mathrm{~s}, t_{(27)}=2.1, p<0.05\right.$, Fig. $\left.2 B\right)$, indicating an increased anxiety in the Trpm $2^{-1-}$ mice. However, the WT $(n=$ 
A

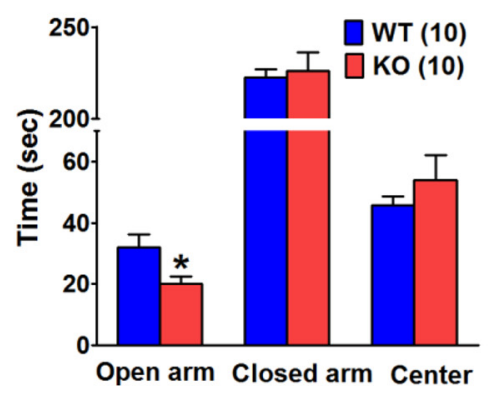

C

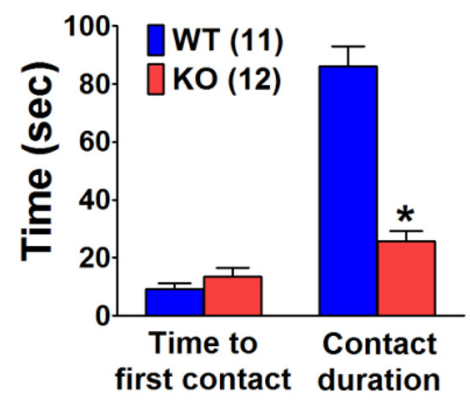

B
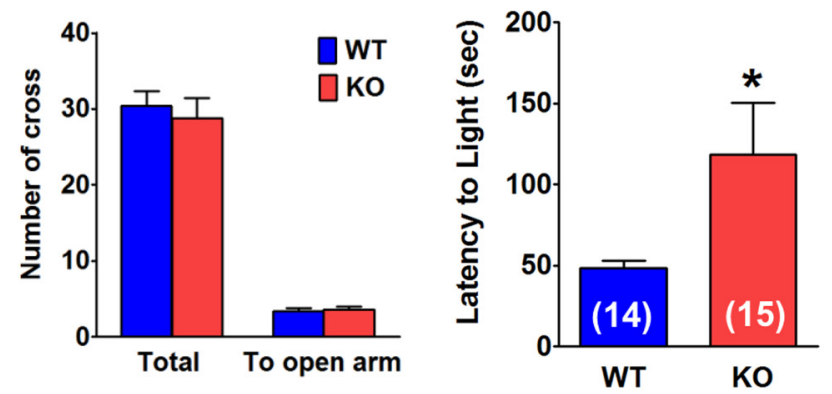

D
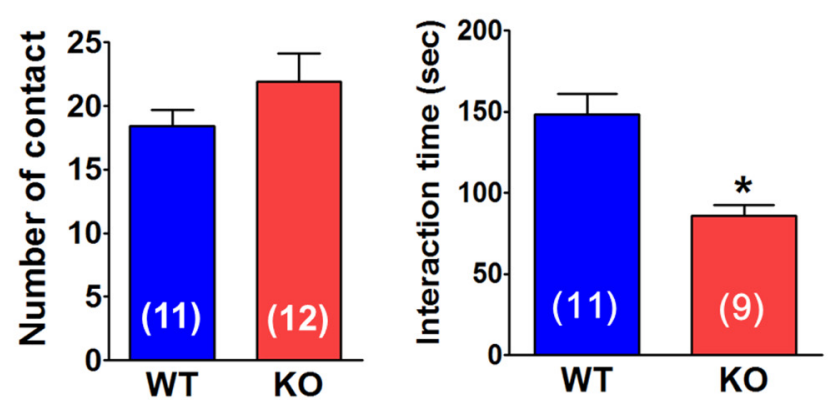

F

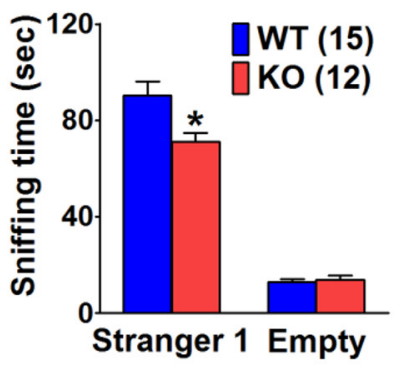

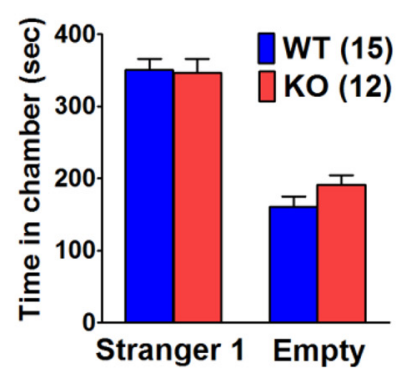

G

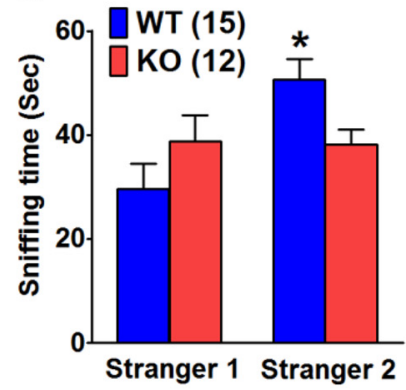

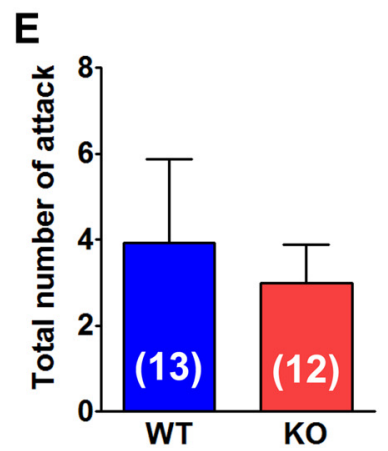

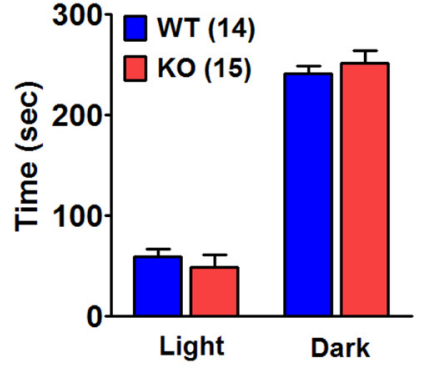

E

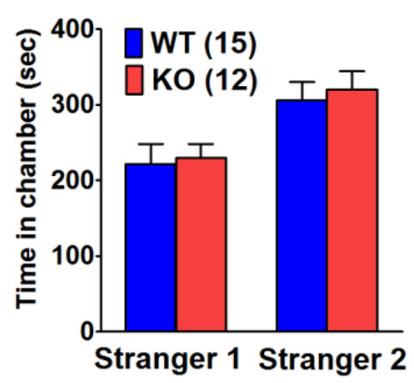

Figure 2. Trpm $2^{-1-}$ mice show increased anxiety and altered social behaviors. $\boldsymbol{A}$, Elevated plus maze task. The time spent (left) and the number of crossings (right) in the open arms over a 5 min period were measured. Note that the time spent was significantly decreased in Trpm $2^{-1}$ - mice compared with WT mice. Numbers in parentheses represent experimental numbers. ${ }^{*} p<0.05$, Student's $t$ test. $\boldsymbol{B}$, Light/dark transition task. The time taken to first enter the light compartment (left) and the time spent in the light and dark over a 5 min period (right) was measured. ${ }^{*} p<0.05$, Student's $t$ test. $C$, Social investigation of an anesthetized mouse target task. A subject mouse was introduced into the corner of a cage in which an anesthetized mouse was lying in the center. The duration and number of contacts (sniffing, touching, and climbing) were measured for 5 min. Note that Trpm $2^{-1-}$ mice showed a similar latency to the first contact with the anesthetized mouse, but the duration of contact was less than that for control mice (left). There was no difference in the number of contact of WT and Trpm2 ${ }^{-\prime-}$ mice (right). ${ }^{* *} p<0.01$, Student's $t$ test. $D$, Social interaction task with a juvenile mouse. A 3- to 4-week-old male mouse and a subject mouse were introduced to a cage. The interaction time with the unfamiliar juvenile mouse was measured. ${ }^{*} p<$ 0.05, Student's $t$ test. $\boldsymbol{E}$, Resident-intruder task. A WT or a Trpm $2^{-1-}$ mouse was housed in isolation for $7 \mathrm{~d}$ before an intruder mouse was introduced into the home cage. Duration of exploration and total number of attacks were measured. There was no difference in total number of attacks to the intruder mouse. $\boldsymbol{F}$, Sociability task. The duration of sniffing and time spent of sniffing in the Stranger 1 cage or the empty cage was measured. Trpm $2^{-1-}$ mice spent less time than WT mice sniffing the Stranger 1 cage (left). Both genotype mice spent similar amounts of time in the two side chambers (right). ${ }^{*} p<0.05$, Student's $t$ test. G, Social novelty preference task. After the sociability test, another male mouse (Stranger 2 ) was introduced to the empty cage. The duration of sniffing and time spent sniffing in each cage were measured. Note that WT mice exhibited a preference for the novel mouse (Stranger 2), whereas Trpm $2^{-1}$ - mice did not show a preference. Trpm2 ${ }^{-1-}$ mice also spent less time than WT mice sniffing the Stranger 2 cage (left). Both genotypes spent similar amounts of time in the two side chambers (right). ${ }^{*} p<0.05$ compared with the duration of sniffing the Stranger 1 cage, Student's $t$ test.

14) and Trpm $2^{-1-}$ mice $(n=15)$ spent similar amounts of time in each chamber of the light-dark box (Fig. $2 B$ ).

The social behavior of the Trpm $2^{-1-}$ mice was assessed through the following tasks: social investigation of an anesthetized mouse target, sociability/social novelty preference, and social interactions with juveniles. In the social investigation of an anesthetized mouse target task, the Trpm $2^{-1-}$ mice spent much less time in contact with an anesthetized mouse compared with the WT mice (Fig. 2C, left, WT; $86.3 \pm 6.9 \mathrm{~s}$ vs KO; $25.7 \pm 3.5 \mathrm{~s}$, $n=11-12$ ). There was no significant difference in the latency to first contact or in the number of contacts with the anesthetized mouse between the two genotypes (Fig. 2C, right, WT; $18.5 \pm$ $1.2 \mathrm{~s}$ vs $\mathrm{KO} ; 21.9 \pm 2.2 \mathrm{~s}, n=11-12$ ). In a social interaction task in which the mice were presented to an unfamiliar juvenile mouse, the Trpm $2^{-1-}$ mice showed a significant reduction in social interaction time compared with the WT mice (Fig. 2D, WT; $148.4 \pm 12.8 \mathrm{~s}$ vs KO; $85.7 \pm 7.1 \mathrm{~s}, n=9-11$ ). Meanwhile, in the resident-intruder task, the Trpm $2^{-1-}$ and WT mice showed a similar number of attacks (Fig. 2E, WT; $3.9 \pm 2.0$ s vs KO; $3.0 \pm$ $0.9 \mathrm{~s}, n=12-13)$, indicating the lack of aggressive behavior in the $\operatorname{Trpm} 2^{-1-}$ mice. On the sociability test, no difference was observed in the amount of time that the WT and Trpm $2^{-1-}$ mice 
A
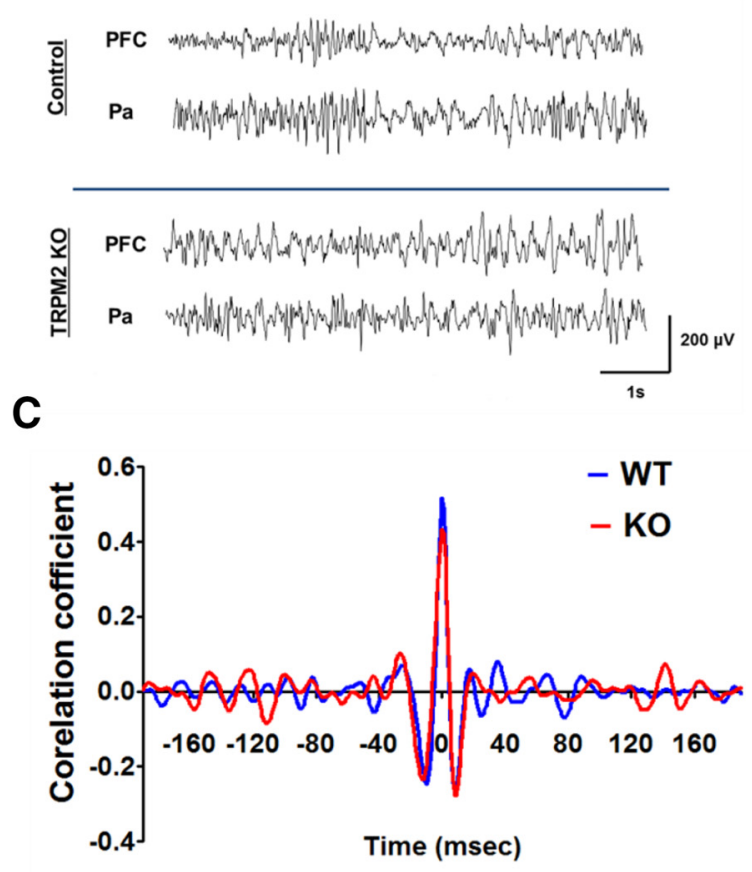

B

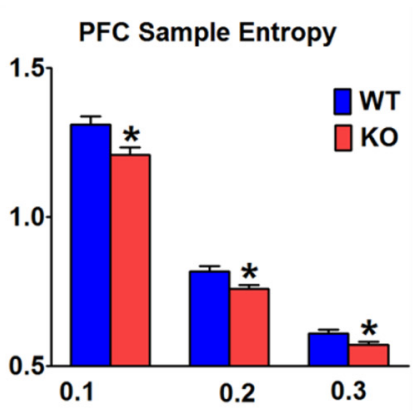

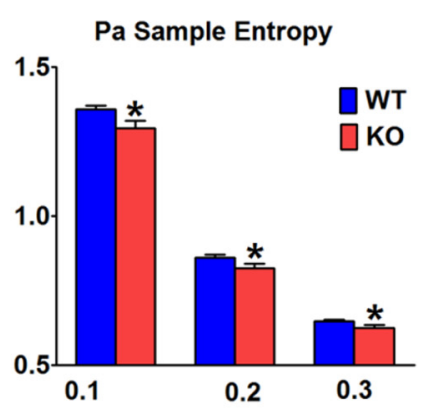

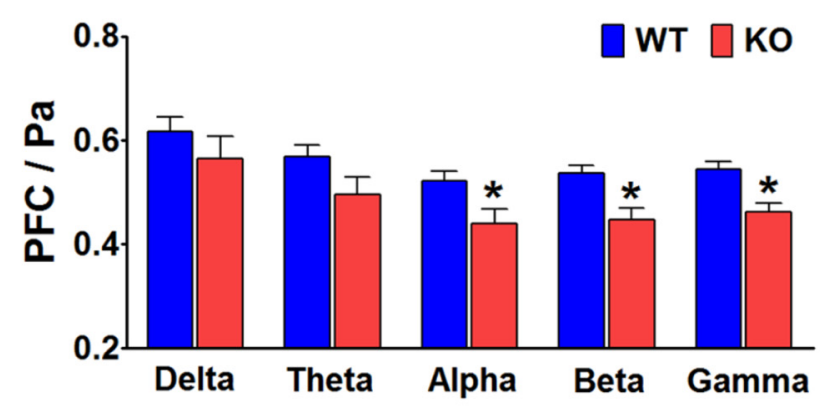

D

Coherence (PFC/Pa)
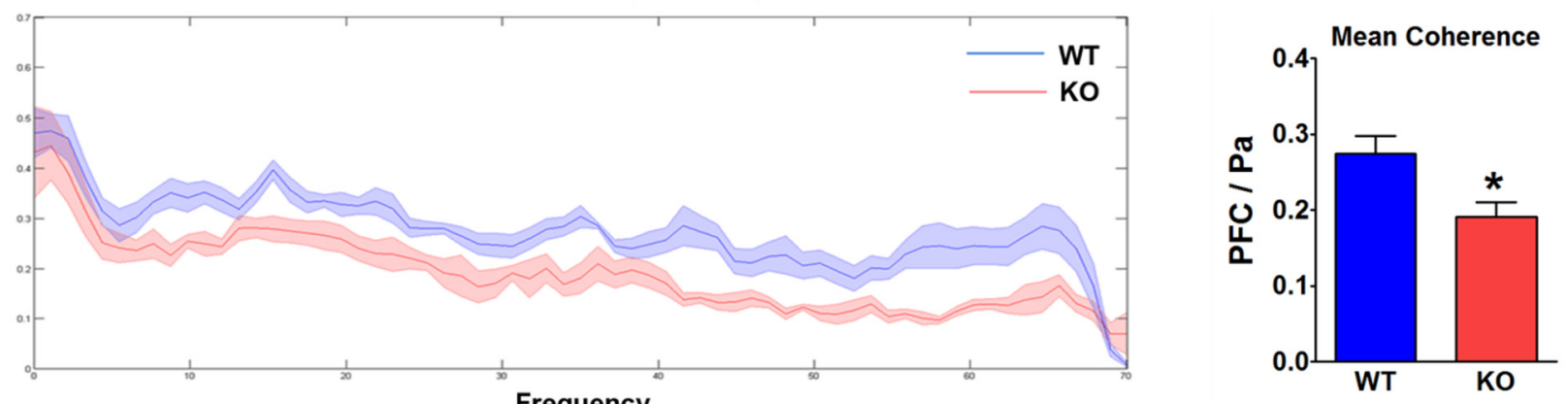

Figure 3. Rhythmic activity in EEG is disturbed in Trpm $2^{-1-}$ mice. $\boldsymbol{A}$, Sample EEG traces recorded in the prefrontal (PFC) and parietal (Pa) cortices. $\boldsymbol{B}$, Sample entropy. The sample entropies of EEG signals from the PFC (left) and Pa (right) were analyzed at $0.1,0.2$, and $0.3 r$ values. Note that $T r p m 2^{-1-}$ mice showed reduced sample entropy in both cortices.. ${ }^{*} p<0.05, n=7$ each genotype, Student's t test. C, Frequency-specific cross-correlation. Representative cross-correlation graphs of correlation coefficient versus time lag (in milliseconds). Cross-correlation analyses of the frontal and parietal EEG signals revealed significant decreases in the correlation coefficient values obtained from the brains of Trpm $2^{-1-}$ mice in the $\alpha$-, $\beta$-, and $\gamma$-frequency ranges, but not the $\delta$ - and $\theta$-frequency ranges. ${ }^{*} p<0.05, n=7$ each genotype, Student's t test. $\boldsymbol{D}$, Coherence. The coherences of frontal and parietal EEG signals $(\sim 0.1-70 \mathrm{~Hz})$ for both genotypes are plotted against the frequency (left). The shaded bars represent error bars with $95 \%$ confidence intervals for the coherence amplitudes of both genotypes. The mean coherence of $T r p m 2^{-~} /-$ mice was significantly reduced compared with that of WT mice (right). ${ }^{*} p<0.05, n=7$ each genotype, Student's $t$ test.

spent in the two chambers (Fig. $2 F$, right). However, the $\operatorname{Trpm} 2^{-1-}$ mice spent significantly less time sniffing a Stranger 1 mouse cage than the WT mice did (Fig. 2F, left, WT; $90.2 \pm 5.9 \mathrm{~s}$ vs $\mathrm{KO} ; 71.0 \pm 3.6 \mathrm{~s}, n=12-15)$. In the subsequent social novelty preference test, the two genotypes spent similar amounts of time in the two chambers (Fig. $2 G$, right). However, the Trpm $2^{-1-}$ mice spent significantly less time in sniffing the Stranger 2 mouse cage than the WT mice (Fig. $2 G$, left, WT; $50.6 \pm 3.9$ s vs KO; $38.2 \pm 2.8 \mathrm{~s}, n=12-15)$. These results indicate decreased sociability and social preference in the Trpm $2^{-1-}$ mice. Together, the results of these behavioral tests suggest increased anxiety or impaired social behavior in Trpm $2^{-1-}$ mice.

Disturbed EEG rhythms in Trpm $2^{-/-}$mice

BD patients exhibited the reduced mean synchronization in the $\alpha$-band observed in frontocentral and centroparietal connections
(Kim et al., 2013). BD patients also show reduced $\gamma$ coherence between frontal and temporoparietal regions (Özerdem et al., 2011). In genetic bipolar mania model with a disrupted circadian gene, CLOCK, an impaired limbic $\gamma$ oscillatory synchrony during anxiety-related behavior was observed (Dzirasa et al., 2011). Because of this disturbed EEG connectivity in BD patients and animal models, we measured EEG signals from the frontal and parietal cortices of WT and Trpm $2^{-1-}$ mice to determine whether there was any aberrant neural activity in the latter. To quantify the changes in the EEG signals, we applied sample entropy, a nonlinear method, to compare the EEG oscillations of the WT and Trpm $2^{-1-}$ mice. The EEG functional connectivity was then quantified using bilinear measures such as crosscorrelation and coherence. Figure $3 A$ shows the sample EEG traces from frontal and parietal cortices. When we calculated sample entropy for the irregularity of EEG oscillations (Fig. 3B), 
A

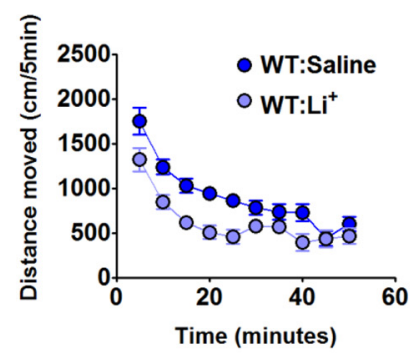

C

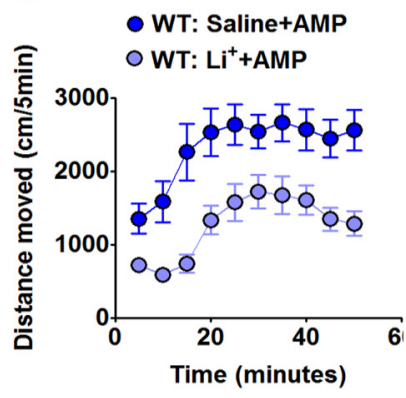

B

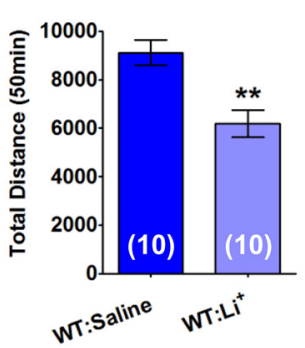

\section{D}

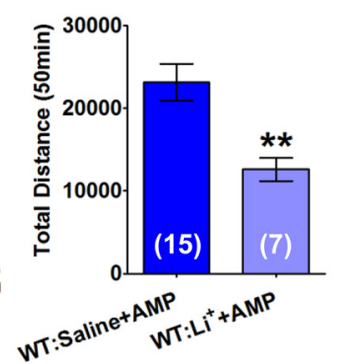

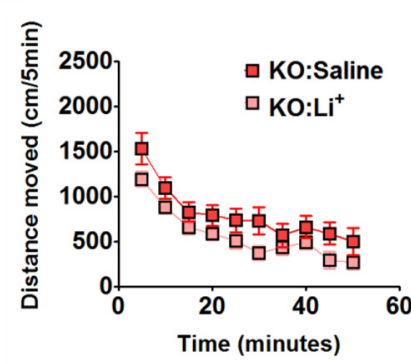

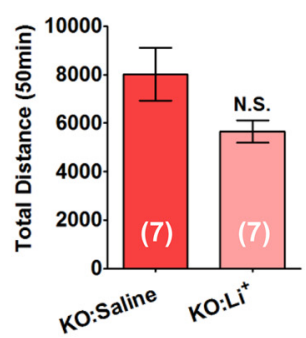

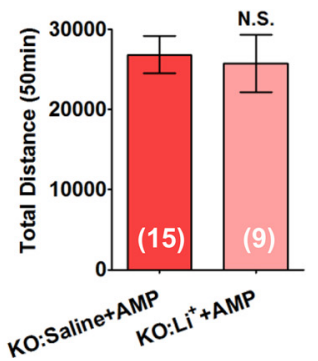

Figure 4. The anti-manic effect of $\mathrm{Li}^{+}$vanishes in $\operatorname{Trpm} 2^{-1-}$ mice. $A, \mathrm{Li}^{+}$treatment reduced the total distance moved in WT mice. The distance moved was measured every 5 min in activity cage. Saline or $\mathrm{Li}^{+}(150 \mathrm{mg} / \mathrm{kg})$ was injected intraperitoneally every day for $5 \mathrm{~d}$. Shown is the summary of the total distance traveled by the WT mice (right). ${ }^{* *} p<0.01$, Student's $t$ test. $\boldsymbol{B}$, There was no the effect of $\mathrm{Li}^{+}$in $T r p m 2^{-1-}$ mice. Shown is the summary of the total distance traveled by $\operatorname{Trpm} 2^{-1-}$ mice (right). N.S., Not significant, Student's $t$ test. $\mathrm{C}$, $\mathrm{Li}^{+}$treatment reduced met-amphetamine-induced hyperactivity in WT mice. Mice were hyperactive when injected with met-amphetamine (AMP) (3 mg/kg, i.p.). The distance moved was measured every 5 min after the met-amphetamine injection. Saline or $\mathrm{Li}^{+}(150 \mathrm{mg} / \mathrm{kg})$ was injected intraperitoneally every day for $5 \mathrm{~d}$. Summary of the total distance traveled by the WT mice (right). ${ }^{* *} p<0.01$, Student's $t$ test. D. The anti-hyperactivity effect of $\mathrm{Li}^{+}$completely vanished in Trpm2 ${ }^{-1-}$ mice. Shown is the summary of the total distance traveled by Trpm2 ${ }^{-1-}$ mice (right). N.S., Not significant, Student's $t$ test.

the $\operatorname{Trpm} 2^{-1-}$ mice showed a decrease in entropy in the frontal and parietal cortices (Fig. $3 B$ ) at different thresholds $(r)$ from those of the WT mice ( $p<0.05, n=7$ each genotype, Student's $t$ test). This indicates increased regularity or decreased complexity in the EEG signals of Trpm $2^{-1-}$ mice. Cross-correlations at each frequency band $(\delta, 1-3.9 \mathrm{~Hz} ; \theta, 4-8 \mathrm{~Hz} ; \alpha, 9-12 \mathrm{~Hz} ; \beta$, $13-30 \mathrm{~Hz} ; \gamma, 31-70 \mathrm{~Hz}$ ) were calculated to analyze the neural synchronization between the frontal and parietal cortices. The correlation coefficients between the two regions in the $\alpha$-, $\beta$-, and $\gamma$-frequency ranges were lower in the Trpm $2^{-1-}$ than in the WT mice ( $p<0.05, n=7$ each genotype, Student's $t$ test; Fig. $3 C$ ), indicating decreased EEG synchronization between the frontal and parietal cortices of the Trpm $2^{-1-}$ mice. To investigate the strength of the spatial correlation between the two brain regions, we performed a coherence analysis on the EEG signals (Fig. 3D). The Trpm $2^{-1-}$ mice showed lower coherence values between the two regions than the WT mice (Fig. 3D, left). Consistent with the result of the cross-correlation analysis, there was a significant difference in the mean coherence between the two genotypes ( $p<0.05, n=7$, Student's $t$ test; Fig. $3 D$, right), which further suggests a weaker association between the frontal and parietal cortices in the Trpm $2^{-1-}$ mice. These results demonstrate that $\operatorname{Trpm} 2^{-1-}$ mice have reduced functional connectivity.

Augmented phosphorylation of GSK-3 in Trpm $2^{-/-}$mice Such BD-like behaviors, together with the EEG patterns found in the Trpm $2^{-1-}$ mice, confirm the genetic link between TRPM2 and BD. To seek molecular insights into the link, we tested the effect of $\mathrm{Li}^{+}$in Trpm2 $2^{-1-}$ mice because this is the first drug of choice for treating BD (Marmol, 2008). Therefore, the effect of $\mathrm{Li}^{+}$on activity in mice in an open field was determined. As shown in Figure 4, in an open-field test box, mice were active at the initial phase but became gradually less active as time went by. In the basal locomotor activity, there was no significant difference between the two genotypes in the distance moved in the openfield test (WT; $9115.9 \pm 520.7 \mathrm{~cm}$ vs $\mathrm{KO} ; 8011.6 \pm 1088.3 \mathrm{~cm}$, $n=7-10$; Fig. $4 A, B$ ). Similarly, the two genotypes showed equal latency to fall in the rotarod test (WT; $300.2 \pm 31.1 \mathrm{~s}$ vs $\mathrm{KO}$; $353.5 \pm 29.1 \mathrm{~s}, n=13)$. Chronic $\mathrm{Li}^{+}$treatment in the WT mice for $5 \mathrm{~d}(150 \mathrm{mg} / \mathrm{kg}$, i.p.) significantly reduced the total distance moved (Fig. 4A, $t_{(18)}=3.8, p<0.01$ ). $\mathrm{Li}^{+}$treatment in $\operatorname{Trpm} 2^{-1-}$ mice also reduced the total distance moved, but not statistically significantly (Fig. $4 B, t_{(12)}=2.0, p=0.07$ ). To determine the effect of $\mathrm{Li}^{+}$on Trpm2 $2^{-1-}$ mice more clearly, the locomotor activity with a hyperactive manic model was measured. The administration of amphetamines to rodents has been broadly used as an animal model for the manic state (O'Donnell and Gould, 2007). The administration of met-amphetamine markedly increased the open-field activity of both genotypes (Fig. $4 C, D)$. When $\mathrm{Li}^{+}$was administered for $5 \mathrm{~d}$ to WT mice, they showed a significant reduction in met-amphetamine-induced hyperactivity (Fig. $4 C, t_{(20)}=3.1, p<0.01$ ). However, the antimanic action of $\mathrm{Li}^{+}$on amphetamine-induced hyperactivity was completely absent in the Trpm $2^{-1-}$ mice (Fig. 4D).

The major action of $\mathrm{Li}^{+}$in treating BD is reducing GSK-3 activity in two inhibitory actions. One is to act as a competitive inhibitor to a cofactor, $\mathrm{Mg}^{2+}$ (direct action), which is necessary for the phosphorylation of target proteins (Ryves and Harwood, 2001). The other is to increase the phosphorylation on the inhibitory Ser residue of GSK-3 (indirect action) (Li et al., 2010). Because of the difficulty of measuring the direct action of $\mathrm{Li}^{+}$due to the complexity of target proteins of 
A

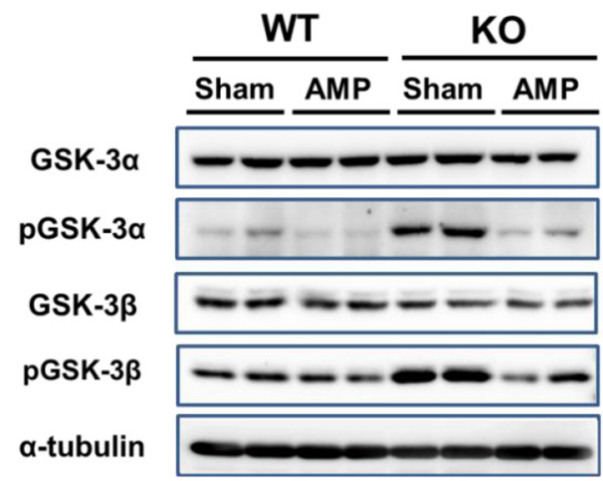

D

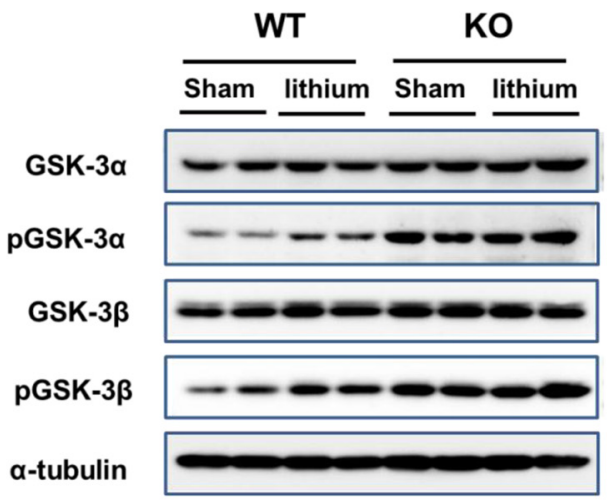

B

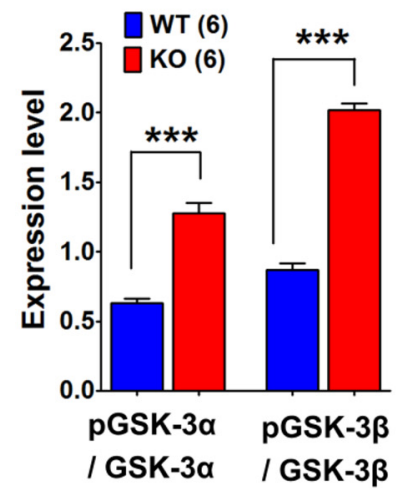

E

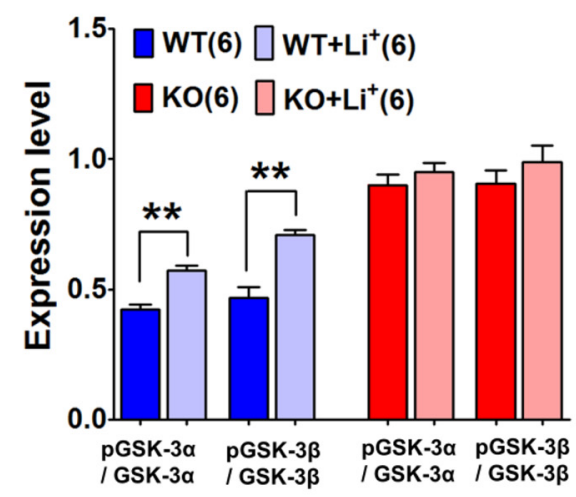

C

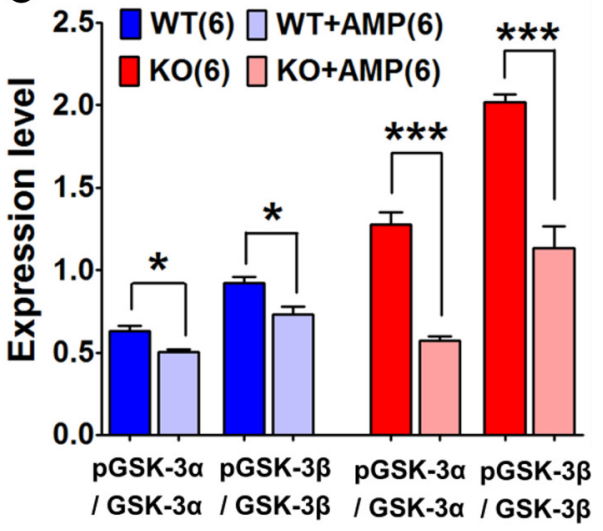

$\mathbf{F}$

Figure 5. Inhibitory phosphorylation on GSK-3 is increased in Trpm2 $2^{-1-}$ mice. $\boldsymbol{A}$, Representative Western blots of total and phosphorylated GSK-3 $\alpha$ and GSK-3 $\beta$ obtained from the frontal cortices of saline (Sham) or amphetamine-treated (AMP) WT and Trpm $2^{-1-}$ mice. Protein samples were acquired 30 min after the injection of saline or AMP. $\boldsymbol{B}$, Quantitative comparisons of the levels of phosphorylated GSK-3 $\alpha$ and GSK-3 $\beta$ obtained from frontal cortices of saline-treated WT and Trpm $2^{-1-}$ mice. The levels of phosphorylated GSK-3 $\alpha$ and GSK-3 $\beta$ were normalized to the levels of total GSK-3 $\alpha$ and GSK-3 $\beta$, respectively. ${ }^{* * *} p<0.001$, Student's $t$ test. C, Summary of the effects of AMP on GSK-3 $\alpha$ and GSK-3 $\beta$ phosphorylations in the frontal cortices of WT and Trpm $2^{-1-}$ mice. ${ }^{*} p<0.05,{ }^{* *} p<0.01$, Student's $t$ test. $\boldsymbol{D}$, Representative Western blots of total and phosphorylated GSK-3 $\alpha$ and GSK-3 $\beta$ from the frontal cortices of saline (sham) or $\mathrm{Li}^{+}$-treated WT and Trpm2 ${ }^{-1-}$ mice. Western blots were conducted with protein samples acquired from the frontal cortices of WT and Trpm2 ${ }^{-/-}$mice administered with saline or $\mathrm{Li}^{+}$(150 $\mathrm{mg} / \mathrm{kg}$, i.p.) daily for $5 \mathrm{~d}$. $\boldsymbol{E}$, Summary of the effects of $\mathrm{Li}^{+}$on GSK-3 $\alpha$ and GSK-3 $\beta$ phosphorylations in the frontal cortices of WT and Trpm2 ${ }^{-1}-$ mice. Note that the administration of Li $^{+}$ significantly augmented the expression levels of phosphorylated GSK-3 $\alpha$ and GSK-3 $\beta$ compared with those treated with saline; however, the Li ${ }^{+}$effect was not observed in Trpm ${ }^{-}{ }^{\prime}-$ mice. , Western blots of $\beta$-catenin from frontal cortices of saline-treated WT and Trpm $2^{-1}$ - mice. The level of $\beta$-catenin was normalized to the level of $\alpha$-tubulin (bottom). ${ }^{* *} p<0.01$, Student's $t$ test.

GSK-3, we first compared the phosphorylation at the inhibitory sites of GSK- $3 \alpha$ and GSK- $3 \beta$ forms in the frontal cortices of both genotypes. The application of amphetamine $(4 \mathrm{mg} / \mathrm{kg}$, i.p.) to WT mice significantly reduced the levels of phosphorylation on the Ser residues of GSK- $3 \alpha$ and GSK-3 $\beta\left(_{(10)}=3.4\right.$ for $\alpha$ form; $t_{(10)}=3.0$ for $\beta$ form, $\left.p<0.05\right)$ compared with those of sham-treated animals, as reported by others (Fig. 5A,C; Beaulieu et al., 2004; Xu et al., 2011). Surprisingly, a dramatic increase in the levels of phosphorylated GSK-3 $\alpha$ and GSK $-3 \beta$ on the Ser residues was detected in the frontal cortices of the Trpm $2^{-1-}$ mice compared with those of the shamtreated WT mice (Fig. $5 A, B ; t_{(10)}=7.7$ for $\alpha$ form; $t_{(10)}=16.8$ for $\beta$ form, $p<0.001$ ), which was also significantly reduced by the amphetamine treatment $\left(t_{(10)}=8.6\right.$ for $\alpha$ form; $t_{(10)}=6.3$ for $\beta$ form, $p<0.001)$. Chronic administration of $\mathrm{Li}^{+}$to WT mice significantly increased the phosphorylation of GSK-3 $\alpha$ and GSK- $3 \beta\left(_{(10)}=5.3\right.$ for $\alpha$ form; $t_{(10)}=5.2$ for $\beta$ form, $p<$ 0.01 ; Fig. $5 D, E)$. In contrast, the administration of $\mathrm{Li}^{+}$to Trpm $2^{-1-}$ mice failed to augment the levels of phosphorylated GSK- $3 \alpha$ and GSK-3 $\beta$ (Fig. $5 D, E$ ), presumably because GSK- $3 \alpha$ and GSK- $3 \beta$ phosphorylation was maximally increased in the brains of these mice before the $\mathrm{Li}^{+}$treatment. Therefore, the lack of augmented phosphorylation of GSK-3 $\alpha$ and GSK-3 $\beta$ may account for the absence of the $\mathrm{Li}^{+}$effect on the amphetamine-induced hyperactivity. Furthermore, because one of the downstream substrates of GSK-3 is $\beta$-catenin, we assessed the GSK-3 activity by measuring the level of $\beta$-catenin. GSK-3 phosphorylates $\beta$-catenin on serine residues, resulting in the degradation of $\beta$-catenin by E3 ubiquitin ligase $\beta$-TrCP (Stamos and Weis, 2013). Therefore, we assumed that the cellular $\beta$-catenin level is increased because a prolonged inhibition of the GSK-3 activity in Trpm $2^{-1-}$ mice would lead to a deficit in the phosphorylation of $\beta$-catenin. As expected, the total level of $\beta$-catenin was significantly increased in the TRPM2 KO mice (Fig. $5 F$ ), indicating the loss of function of GSK-3 in Trpm $2^{-1-}$ mice.

\section{TRPM2 activation regulates GSK-3}

To further investigate the molecular mechanism underlying the augmented phosphorylation of GSK-3 on the Ser residues in the cerebral cortices of Trpm $2^{-1-}$ mice, pharmacological perturbation of the TRPM2/GSK-3 pathway was applied. Because TRPM2 is a $\mathrm{Ca}^{2+}$-permeable channel activated by oxidative stress such as $\mathrm{H}_{2} \mathrm{O}_{2}$ (Kühn et al., 2005), we applied $700 \mu \mathrm{M} \mathrm{H}_{2} \mathrm{O}_{2}$ to Neuro-2a cells. The application of $\mathrm{H}_{2} \mathrm{O}_{2}$ significantly decreased the levels of phosphorylated GSK- $3 \alpha$ and GSK- $3 \beta$, which were reversed by 
A

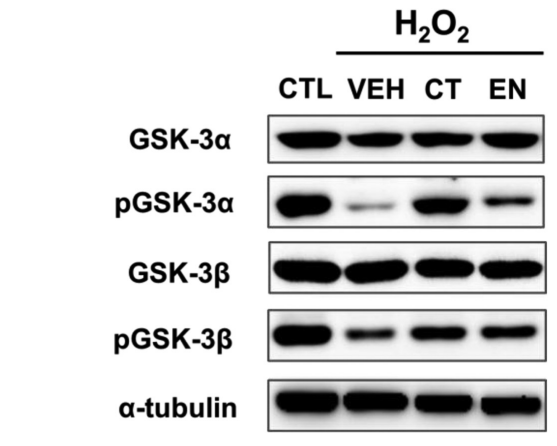

B
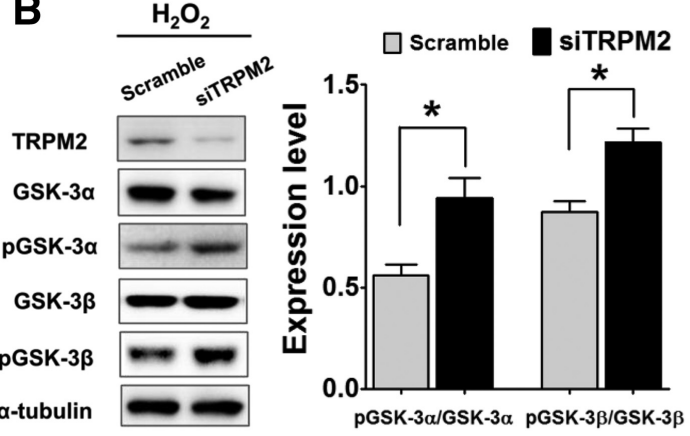

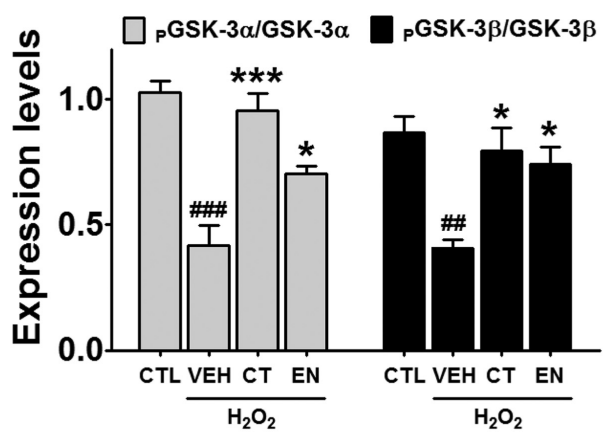

C

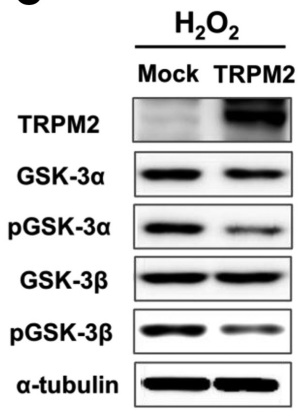

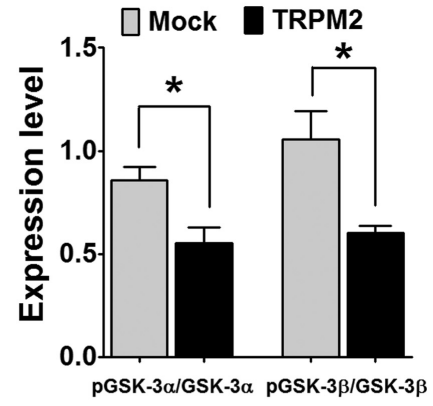

D
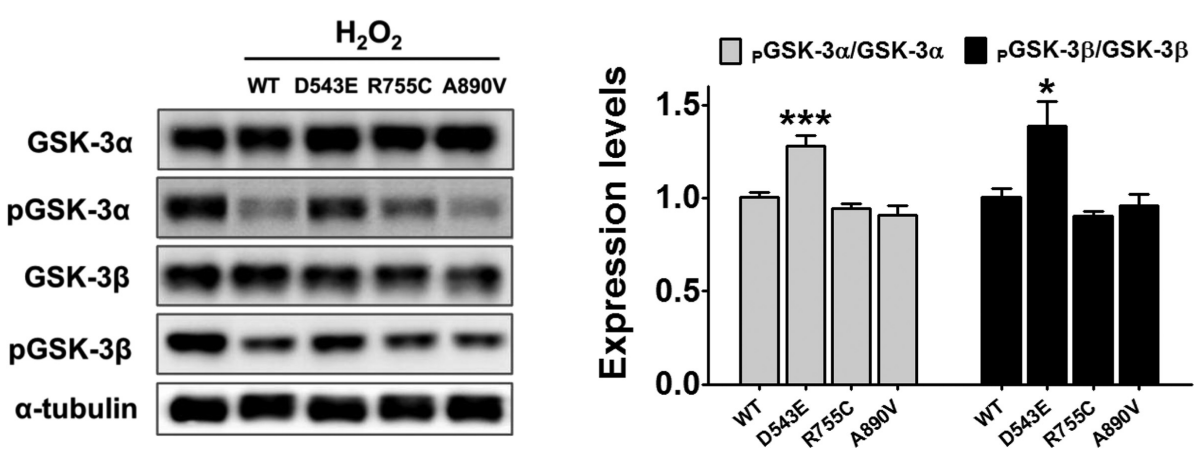

Figure 6. TRPM2 activation inhibits the phosphorylation of GSK-3 $\alpha$ and GSK-3 $\beta$. A, Western blot analysis of the dephosphorylation of GSK-3 $\alpha$ and GSK-3 $\beta$ on Ser residues induced by the activation of TRPM2 by $\mathrm{H}_{2} \mathrm{O}_{2}$. Neuro-2a cells were treated with $700 \mu_{\mathrm{m} \mathrm{H}} \mathrm{O}_{2}$ for 30 min either with or without (vehicle, VEH) $30 \mu \mathrm{m}$ clotrimazol (CT) or $30 \mu \mathrm{m} \mathrm{econazol}$ (EN) (left). Lysates of Neuro-2a cells were blotted with antibodies of nonphosphorylated or Ser-phosphorylated GSK-3 $\alpha$ or GSK-3 $\beta$ (left). Shown is the summary of the effects of $\mathrm{H}_{2} \mathrm{O}_{2}$ applications on the relative levels of phosphorylated GSK- $3 \alpha$ and GSK-3 $\beta$ (right). The relative levels are calculated as the intensity of phosphorylated GSK- $3 \alpha$ and GSK-3 $\beta$ divided by the intensity of nonphosphorylated GSK-3 $\alpha$ and GSK-3 $\beta(n=3) .{ }^{*} p<0.05,{ }^{* *} p<0.01,{ }^{* * *} p<0.001$, one-way ANOVA, Tukey's post hoc test. B, Trpm2-gene knock-down in Neuro-2a cells induced an increase in the phosphorylation of GSK-3 $\alpha$ and GSK-3 $\beta$. Shown are representative Western blots (left) and a summary of the quantitative analyses (right). ${ }^{*} p<0.05$, Student's $t$ test. C, Overexpression of TRPM 2 in Neuro-2a cells reduced the levels of phosphorylated GSK-3 $\alpha$ and GSK-3 $\beta$ on Ser residues. Shown are representative Western blots (left) and a summary of the effect of TRPM2 overexpression on the levels of phosphorylated GSK-3 $\alpha$ and GSK-3 $\beta$ (right). ${ }^{*} p<0.05$, Student's $t$ test. $\boldsymbol{D}$, Overexpression of D543E mutant TRPM2 in Neuro-2a cells rescued the TRPM2-dependent dephosphorylation of GSK-3 $\alpha$ and GSK-3 $\beta$. Shown are representative Western blots (left) and a summary of the effects of TRPM2 and its mutant overexpression on the levels of phosphorylated GSK-3 $\alpha$ and GSK-3 $\beta$ (right). ${ }^{* * *} p<0.001$, ${ }^{*} p<0.05$, one-way ANOVA, Tukey's post hoc test.

coapplication of the TRPM2 blockers econazol or clotrimazol (both $30 \mu \mathrm{M}$; Fig. $6 A ; F_{(3,8)}=21.4$ for $\alpha$ form and $F_{(3,8)}=9.1$ for $\beta$ form, $p<0.01$ and $p<0.001$ vs the untreated control, respectively; $p<0.05$ and $p<0.001$ vs the untreated vehicle, respectively, one-way ANOVA). These TRPM2 blockers effectively inhibited the $\mathrm{H}_{2} \mathrm{O}_{2}$-induced $\mathrm{Ca}^{2+}$ influx in Neuro-2a cells (data not shown). In the absence of $\mathrm{H}_{2} \mathrm{O}_{2}$, econazol and clotrimazol failed to change the level of phosphorylated GSK-3 (data not shown). These results further suggest that the inhibition of TRPM2 upregulates inhibitory phosphorylation on GSK-3 $\alpha$ and GSK-3 $\beta$.

The functional link between TRPM2 and GSK- 3 was further confirmed with the knock-down or overexpression of TRPM2. As shown in Figure 6, B and C, Trpm2 siRNA-treated Neuro-2a cells exhibited significant upregulation of GSK- $3 \alpha$ and GSK- $3 \beta$ phosphorylation (Fig. $6 B, t_{(4)}=3.4$ for $\alpha$ form; $t_{(4)}=4.0$ for $\beta$ form, $p<0.05$ ), whereas a marked reduction in the phosphorylation GSK- $3 \alpha$ and GSK-3 $\beta$ was detected when Neuro-2a cells were transfected with Trpm 2 (Fig. $6 C, t_{(4)}=3.1$ for $\alpha$ form; $t_{(4)}=$ 3.2 for $\beta$ form, $p<0.05$ ). More importantly, when the loss-offunction mutant D543E was overexpressed, a significant increase in the phosphorylation of GSK- $3 \alpha$ and GSK- $3 \beta$ was detected compared with that of WT, R755C, and A890V mutant TRPM2expressing cells (Fig. $6 D, F_{(3,24)}=16.5$ for $\alpha$ form, $p<0.01 ; F_{(3,33)}=6.8$ for $\beta$ form, $p<0.05$ vs WT, one-way ANOVA).

Because TRPM2 is a $\mathrm{Ca}^{2+}$-permeable cation that permits $\mathrm{Ca}^{2+}$ inflow, we hypothesized that TRPM2 may control GSK-3 
phosphorylation via a $\mathrm{Ca}^{2+}$-sensitive phosphatase, calcineurin. Indeed, the $\mathrm{H}_{2} \mathrm{O}_{2}$-induced reduction in the phosphorylation of GSK- $3 \alpha$ and GSK- $3 \beta$ was blocked by treatment with the calcineurin inhibitors cyclosphorin A and FK-506 in native (Fig. 7A; $F_{(3,20)}=43.7$ for $\alpha$ form and $F_{(3,30)}=19.1$ for $\beta$ form, $p<0.001$ vs the untreated control and $p<0.01$ vs the untreated vehicle, one-way ANOVA) and Trpm2-transfected (Fig. $7 B ; F_{(3,26)}=12.3$ for $\alpha$ form and $F_{(3,30)}=8.9$ for $\beta$ form, $p<0.001$ vs the untreated control, $p<$ 0.05 , and $p<0.01$ vs the untreated vehicle, one-way ANOVA) Neuro-2a cells. These results suggest that TRPM2dependent dephosphorylation of GSK- $3 \alpha$ and GSK-3 $\beta$ is mainly dependent on calcineurin.

\section{Discussion}

Although many people suffer from BD, its pathology is not well understood. Genetic linkage analyses of BD patients have found strong associations between mutations in Trpm2 and BD (Kostyrko et al., 2006; McQuillin et al., 2006; Xu et al., 2009). Despite this evidence of a genetic link, its etiologic mechanism is not known. In the present study, we tested the functional roles of D543E, R755C, and A890C mutants of Trpm2, which are found in $\mathrm{BD}$ patients. Among these, the D543E mutant elicited a loss of function, suggesting that the loss of function of TRPM2 could lead to BD. Consistent with this assumption, Trpm2-deficient mice exhibited increased anxiety and impairments in social cognition, with irregular EEG rhythms. TRPM2 appears to be actively involved in regulating the phosphorylation of GSK-3. Inhibition of TRPM2 activity led to upregulation of the inhibitory phosphorylation of GSK-3, whereas stimulation of TRPM2 downregulated the GSK-3 phosphorylation, possibly via calcineurin. Because changes in GSK-3 activity are associated with psychiatric disorders (Li et al., 2010; Pandey et al., 2010), the present findings suggest that chronic dysfunction of $\operatorname{Trpm} 2$ activity due to genetic mutations impairs the dephosphorylation of GSK-3, which may eventually lead to the pathology of psychiatric disease.

\section{TRPM2 mutations in BD patients}

Linkage analyses of BD families suggest an association between Trpm2 and BD. The identified susceptible chromosomal locus in BD families, 21q22.3, contains the Trpm2 gene (Straub et al., 1994; Nagamine et al., 1998). Cohort analyses indicate that $\mathrm{BD}$ is associated with mutations in the Trpm2 coding sequence: D543E, R755C, and A890V (Kostyrko et al., 2006; McQuillin et al., 2006; Xu et al., 2009). Moreover, Trpm2 has been suggested to be involved in insulin secretion (Togashi et al., 2006) and it is noteworthy that BD and type 2 diabetes mellitus are strongly associated (Regenold et al., 2002). In addition, TRPM2 induces chemokine production in mono-
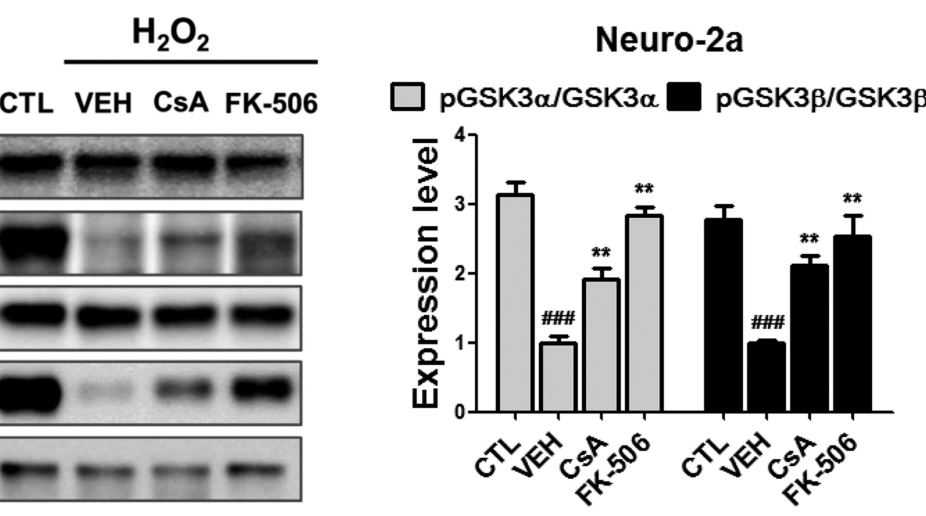

Figure 7. The calcineurin inhibitors cyclosporine A and FK-506 suppress the TRPM2-dependent dephosphorylation of GSK-3 $\alpha$ and GSK-3 $\beta$. A, Western blot analysis of the dephosphorylation of GSK-3 $\alpha$ and GSK-3 $\beta$ induced by the activation of native TRPM2 by $\mathrm{H}_{2} \mathrm{O}_{2}$ in Neuro-2a cells. Neuro-2a cells were treated for $1 \mathrm{~h}$ with the calcineurin blockers $10 \mu \mathrm{m}$ cyclosporine $\mathrm{A}$ (CsA) or $1 \mu \mathrm{M}$ the untreated vehicle (VEH), one-way ANOVA, Tukey's post hoc test. B, Cyclosporine A and FK-506 suppressed the dephosphorytransfected Neuro-2a cells were treated with $10 \mu \mathrm{m}$ (sA or $1 \mu \mathrm{m}$ FK-506 for $1 \mathrm{~h}$ together with or without (CTL) $\mathrm{H}_{2} \mathrm{O}_{2}$ (right). Shown transfected Neuro-2a cells (left). \#\#\# $<0.001$ versus the untreated CTL; ${ }^{*} p<0.05,{ }^{* *} p<0.01$ versus the untreated VEH, one-way ANOVA, Tukey's post hoc test.

cytes (Yamamoto et al., 2008). Interestingly, BD patients have high serum interleukin levels (Ortiz-Domínguez et al., 2007). These findings support a strong association between the Trpm 2 mutation and BD.

Among the TRPM2 mutants found in BD patients, the D543E mutant elicited a prominent loss of function in ADPR or $\mathrm{H}_{2} \mathrm{O}_{2}-$ driven stimulation, which is largely consistent with clinical reports for its strong association with BD. McQuillin et al. (2006) reported that the D543E transition has the strongest association with BD $(p=0.008)$. Moreover, Xu et al. (2009) emphasized a significant association of D543E through a family-based association study. In the present study, other mutants such as R755C and A890V failed to show a discernible change in channel activity. However, this does not exclude the possible pathogenesis of $\mathrm{BD}$ with these mutations. At present, it is not known how these mutants are involved in $\mathrm{BD}$. R755C and A890V mutants may cause a loss of function too small to be detected by current recordings. If the small change in activity becomes chronic, the abnormal activity may result in the neural basis for psychiatric disorder. However, mechanisms other than the change in the TRPM2/GSK-3 pathway may also be involved in the pathology of $\mathrm{BD}$. 


\section{GSK-3 activity controls mood}

GSK-3 is a serine/threonine protein kinase composed of two isoforms: GSK-3 $\alpha$ and GSK-3 $\beta$. In mammals, GSK-3 is known to regulate glucose homeostasis by mediating the phosphorylation of glycogen synthase (Cole, 2013). However, GSK-3 mediates multiple physiological functions in the brain, such as the circadian rhythm, neurogenesis, and neurotransmission (Cole, 2013). Given its key role in multiple functions, its activity is tightly regulated by an active or inhibitory phosphorylation residue (Li et al., 2010). For example, phosphorylation of the serine 9 residue in GSK- $3 \beta$ leads to a reduction in its kinase activity, whereas phosphorylation of the tyrosine 216 residue enhances it (Li et al., 2010; Cole, 2013). Furthermore, changes in GSK-3 activity alter animal behavior. Transgenic mice overexpressing GSK- $3 \beta$ show hyperactive locomotion, whereas the reduced activity shown in GSK$3 \alpha^{-/-}$or GSK-3 $\beta^{+/-}$mice leads to depressive behavior (O'Brien et al., 2004; Kaidanovich-Beilin et al., 2009). Transgenic mice with the constitutively active form of GSK-3 (mutations in the inhibitory serine residue of GSK- $3 \alpha$ and GSK-3 $\beta$ ) display increased sensitivity to amphetamine-induced hyperactivity and stress-induced depressive behavior (Polter et al., 2010). Consistent with this, the Trpm $2^{-1-}$ mice in this study displayed severe social impairment with augmented phosphorylation in the inhibitory serine residues of GSK-3, thus providing further support for the etiologic mechanism underlying the genetic link between TRPM2 and BD.

\section{Clinical evidence for GSK-3 and BD}

Given its involvement in neurogenesis, neuronal differentiation, and neuronal cell death (Hur and Zhou, 2010), the dysfunction of GSK-3 is associated with multiple psychiatric and neurodegenerative diseases, including $\mathrm{BD}$. Gene polymorphisms in the GSK-3 $\beta$ promoter region have been reported in BD and schizophrenic patients (Lin et al., 2013; Tang et al., 2013). Kozlovsky et al. $(2000,2001)$ found low immunoreactivity and GSK-3 $\beta$ activity in the frontal cortices of schizophrenic patients postmortem. Therefore, proper control of GSK-3 activity with excitatory or inhibitory phosphorylation may be required for mood stabilization. Indeed, numerous clinical studies suggest a link between BD and abnormal GSK-3 activity in the brain. Samples of platelets from drug-free patients with $\mathrm{BD}$ were found to have significantly reduced total GSK-3 $\beta$, whereas those from $\mathrm{BD}$ patients taking mood-stabilizing drugs had GSK- $3 \beta$ levels comparable to those of healthy subjects (Pandey et al., 2010). In another study, the levels of total GSK-3 in BD patients were higher than those of the healthy group (Li et al., 2010). Treatment with a mood-stabilizing drug for 8 weeks induced an anti-manic effect and increased phosphorylated GSK-3 on the Ser residue without changing its total level (Li et al., 2010). Therefore, it seems clear that treatment with mood-stabilizing drugs including $\mathrm{Li}^{+}$alleviates the manic symptoms of $\mathrm{BD}$ along with augmented phosphorylation of GSK-3 on the Ser residue.

\section{Behavior of Trpm2 $2^{-1-}$ mice}

Neurophysiological measures such as EEG are used to analyze synchronization and oscillatory activity with a high temporal resolution. EEG functional connectivity is disrupted in psychiatric disorders such as BD (Chai et al., 2011; Kim et al., 2013; Mamah et al., 2013). In the present study, Trpm $2^{-1-}$ mice showed a significant decrease in frontoparietal synchronization and coherence at high-frequency bands ( $\alpha-, \beta$-, and $\gamma$-bands). This disrupted functional connectivity may imply abnormal behavior in $\operatorname{Trpm} 2^{-1-}$ mice. Recently, various animal models, including ge- netically engineered mice, have been used in investigations designed to investigate the pathophysiology of mood disorders (Nestler and Hyman, 2010; Kulak et al., 2013). Trpm2 $2^{-1-}$ mice showed alterations in amphetamine-induced locomotion, anxiety behavior, and social cognition, which are typical symptoms of BD patients (Belmaker and Bersudsky, 2004; Greenberg et al., 2014).

\section{Calcineurin dephosphorylates GSK-3}

Because TRPM2 is activated by reactive oxygen species, TRPM2 functions as an oxidative sensor (Kühn et al., 2005). TRPM2 is a cation channel that is also permeable to $\mathrm{Ca}^{2+}$. Therefore, its activation by oxidative stress induces intracellular $\mathrm{Ca}^{2+}$, which activates a $\mathrm{Ca}^{2+}$-dependent protein phosphatase, calcineurin. Calcineurin is known to dephosphorylate GSK-3 on the inhibitory Ser residue, which activates GSK-3 to scavenge or rescue cells from oxidative stress (Kim et al., 2009). Therefore, when loss-offunction mutations in TRPM2 occur, the dysfunction of TRPM2 induces the abnormal accumulation of inactive GSK-3 due to the downregulation of calcineurin. Consistent with this hypothesis, the present study showed that phosphorylation of GSK-3 on the Ser residue was markedly increased in $\operatorname{Trpm} 2^{-1-}$ mice. When TRPM2 was overexpressed, the phosphorylation was significantly reduced, which was partly recovered when calcineurin was inhibited. Therefore, an alteration in TRPM2 activity leads to a change in GSK-3 activity. In the present study, administration of $\mathrm{Li}^{+}$to WT mice suppressed amphetamine-induced hyperactivity, but this anti-manic effect of $\mathrm{Li}^{+}$was not present in Trpm $2^{-1-}$ mice (Fig. 4). It is possible that the $\mathrm{Li}^{+}$treatment did not further augment GSK-3 phosphorylation in the Trpm $2^{-1-}$ mice because GSK-3 was already maximally phosphorylated in this genotype (Fig. 5).

In summary, this study provides a potential mechanistic link between BD and mutations of Trpm2. TRPM2 appears to control the activity of GSK-3, the key enzyme for controlling mood, possibly via calcineurin. Therefore, the loss-of-function mutations in Trpm2 lead to abnormal GSK-3 activity, leading to abnormal changes in mood. These findings suggest a novel therapeutic strategy for treating TRPM2-linked BD patients.

\section{References}

Andreazza AC, Wang JF, Salmasi F, Shao L, Young LT (2013) Specific subcellular changes in oxidative stress in prefrontal cortex from patients with bipolar disorder. J Neurochem 127:552-561. CrossRef Medline

Ballester J, Goldstein B, Goldstein TR, Yu H, Axelson D, Monk K, Hickey MB, Diler RS, Sakolsky DJ, Sparks G, Iyengar S, Kupfer DJ, Brent DA, Birmaher B (2014) Prospective longitudinal course of aggression among adults with bipolar disorder. Bipolar Disord 16:262-269. CrossRef Medline

Beaulieu JM, Sotnikova TD, Yao WD, Kockeritz L, Woodgett JR, Gainetdinov RR, Caron MG (2004) Lithium antagonizes dopamine-dependent behaviors mediated by an AKT/glycogen synthase kinase 3 signaling cascade. Proc Natl Acad Sci U S A 101:5099-5104. CrossRef Medline

Belmaker RH, Bersudsky Y (2004) Bipolar disorder: treatment. Discov Med 4:415-420. Medline

Chai XJ, Whitfield-Gabrieli S, Shinn AK, Gabrieli JD, Nieto Castañón A, McCarthy JM, Cohen BM, Ongür D (2011) Abnormal medial prefrontal cortex resting-state connectivity in bipolar disorder and schizophrenia. Neuropsychopharmacology 36:2009-2017. CrossRef Medline

Cho H, Jang Y, Lee B, Chun H, Jung J, Kim SM, Hwang SW, Oh U (2013) Voluntary movements as a possible non-reflexive pain assay. Mol Pain 9:25. CrossRef Medline

Cole AR (2013) Glycogen synthase kinase 3 substrates in mood disorders and schizophrenia. FEBS J 280:5213-5227. CrossRef Medline

Cusi AM, Nazarov A, Holshausen K, Macqueen GM, McKinnon MC (2012) Systematic review of the neural basis of social cognition in patients with mood disorders. J Psychiatry Neurosci 37:154-169. CrossRef Medline 
Dzirasa K, McGarity DL, Bhattacharya A, Kumar S, Takahashi JS, Dunson D, McClung CA, Nicolelis MA (2011) Impaired limbic $\gamma$ oscillatory synchrony during anxiety-related behavior in a genetic mouse model of bipolar mania. J Neurosci 31:6449-6456. CrossRef Medline

Frey BN, Valvassori SS, Réus GZ, Martins MR, Petronilho FC, Bardini K, Dal-Pizzol F, Kapczinski F, Quevedo J (2006) Effects of lithium and valproate on amphetamine-induced oxidative stress generation in an animal model of mania. J Psychiatry Neurosci 31:326-332. Medline

Goldberg JF, Perlis RH, Bowden CL, Thase ME, Miklowitz DJ, Marangell LB, Calabrese JR, Nierenberg AA, Sachs GS (2009) Manic symptoms during depressive episodes in 1,380 patients with bipolar disorder: findings from the STEP-BD. Am J Psychiatry 166:173-181. CrossRef Medline

Gould TD, O’Donnell KC, Picchini AM, Manji HK (2007) Strain differences in lithium attenuation of d-amphetamine-induced hyperlocomotion: a mouse model for the genetics of clinical response to lithium. Neuropsychopharmacology 32:1321-1333. CrossRef Medline

Greenberg S, Rosenblum KL, McInnis MG, Muzik M (2014) The role of social relationships in bipolar disorder: a review. Psychiatry Res 219:248254. CrossRef Medline

Gubert C, Stertz L, Pfaffenseller B, Panizzutti BS, Rezin GT, Massuda R, Streck EL, Gama CS, Kapczinski F, Kunz M (2013) Mitochondrial activity and oxidative stress markers in peripheral blood mononuclear cells of patients with bipolar disorder, schizophrenia, and healthy subjects. J Psychiatr Res 47:1396-1402. CrossRef Medline

Hur EM, Zhou FQ (2010) GSK3 signalling in neural development. Nat Rev Neurosci 11:539-551. Medline

Jeon D, Kim S, Chetana M, Jo D, Ruley HE, Lin SY, Rabah D, Kinet JP, Shin HS (2010) Observational fear learning involves affective pain system and Cav1.2 Ca2 + channels in ACC. Nat Neurosci 13:482-488. CrossRef Medline

Johnson SL, Sandrow D, Meyer B, Winters R, Miller I, Solomon D, Keitner G (2000) Increases in manic symptoms after life events involving goal attainment. J Abnorm Psychol 109:721-727. CrossRef Medline

Jung S, Seo JS, Kim BS, Lee D, Jung KH, Chu K, Lee SK, Jeon D (2013) Social deficits in the AY-9944 mouse model of atypical absence epilepsy. Behav Brain Res 236:23-29. CrossRef Medline

Kaidanovich-Beilin O, Lipina TV, Takao K, van Eede M, Hattori S, Laliberté C, Khan M, Okamoto K, Chambers JW, Fletcher PJ, MacAulay K, Doble BW, Henkelman M, Miyakawa T, Roder J, Woodgett JR (2009) Abnormalities in brain structure and behavior in GSK- $3 \alpha$ mutant mice. Mol Brain 2:35. CrossRef Medline

Kim DJ, Bolbecker AR, Howell J, Rass O, Sporns O, Hetrick WP, Breier A, O’Donnell BF (2013) Disturbed resting state EEG synchronization in bipolar disorder: A graph-theoretic analysis. Neuroimage Clin 2:414423. CrossRef Medline

Kim Y, Lee YI, Seo M, Kim SY, Lee JE, Youn HD, Kim YS, Juhnn YS (2009) Calcineurin dephosphorylates glycogen synthase kinase- $3 \beta$ at serine- 9 in neuroblast-derived cells. J Neurochem 111:344-354. CrossRef Medline

Kostyrko A, Hauser J, Rybakowski JK, Trzeciak WH (2006) Screening of chromosomal region 21q22.3 for mutations in genes associated with neuronal $\mathrm{Ca} 2+$ signalling in bipolar affective disorder. Acta Biochim Pol 53:317-320. Medline

Kozlovsky N, Belmaker RH, Agam G (2000) Low GSK-3 $\beta$ immunoreactivity in postmortem frontal cortex of schizophrenic patients. Am J Psychiatry 157:831-833. CrossRef Medline

Kozlovsky N, Belmaker RH, Agam G (2001) Low GSK-3 activity in frontal cortex of schizophrenic patients. Schizophr Res 52:101-105. CrossRef Medline

Kühn FJ, Heiner I, Lückhoff A (2005) TRPM2: a calcium influx pathway regulated by oxidative stress and the novel second messenger ADP-ribose. Pflugers Arch 451:212-219. CrossRef Medline

Kulak A, Steullet P, Cabungcal JH, Werge T, Ingason A, Cuenod M, Do KQ (2013) Redox dysregulation in the pathophysiology of schizophrenia and bipolar disorder: insights from animal models. Antioxid Redox Signal 18:1428-1443. CrossRef Medline

Leahy RL (2007) Bipolar disorder: causes, contexts, and treatments. J Clin Psychol 63:417-424. CrossRef Medline

Leverich GS, McElroy SL, Suppes T, Keck PE Jr, Denicoff KD, Nolen WA, Altshuler LL, Rush AJ, Kupka R, Frye MA, Autio KA, Post RM (2002) Early physical and sexual abuse associated with an adverse course of bipolar illness. Biol Psychiatry 51:288-297. CrossRef Medline

Li X, Liu M, Cai Z, Wang G, Li X (2010) Regulation of glycogen synthase kinase-3 during bipolar mania treatment. Bipolar Disord 12:741-752. CrossRef Medline

Lin YF, Huang MC, Liu HC (2013) Glycogen synthase kinase $3 \beta$ gene polymorphisms may be associated with bipolar I disorder and the therapeutic response to lithium. J Affect Disord 147:401-406. CrossRef Medline

Mamah D, Barch DM, Repovš G (2013) Resting state functional connectivity of five neural networks in bipolar disorder and schizophrenia. J Affect Disord 150:601-609. CrossRef Medline

Marmol F (2008) Lithium: bipolar disorder and neurodegenerative diseases Possible cellular mechanisms of the therapeutic effects of lithium. Prog Neuropsychopharmacol Biol Psychiatry 32:1761-1771. CrossRef Medline

Maytal G, Zalta AK, Thompson E, Chow CW, Perlman C, Ostacher MJ, Pollack MH, Shear K, Simon NM (2007) Complicated grief and impaired sleep in patients with bipolar disorder. Bipolar Disord 9:913-917. CrossRef Medline

McQuillin A, Bass NJ, Kalsi G, Lawrence J, Puri V, Choudhury K, DeteraWadleigh SD, Curtis D, Gurling HM (2006) Fine mapping of a susceptibility locus for bipolar and genetically related unipolar affective disorders, to a region containing the C21ORF29 and TRPM2 genes on chromosome 21q22.3. Mol Psychiatry 11:134-142. CrossRef Medline

Moretti P, Bouwknecht JA, Teague R, Paylor R, Zoghbi HY (2005) Abnormalities of social interactions and home-cage behavior in a mouse model of Rett syndrome. Hum Mol Genet 14:205-220. Medline

Moy SS, Nadler JJ, Perez A, Barbaro RP, Johns JM, Magnuson TR, Piven J, Crawley JN (2004) Sociability and preference for social novelty in five inbred strains: an approach to assess autistic-like behavior in mice. Genes Brain Behav 3:287-302. CrossRef Medline

Nadler JJ, Moy SS, Dold G, Trang D, Simmons N, Perez A, Young NB, Barbaro RP, Piven J, Magnuson TR, Crawley JN (2004) Automated apparatus for quantitation of social approach behaviors in mice. Genes Brain Behav 3:303-314. CrossRef Medline

Nagamine K, Kudoh J, Minoshima S, Kawasaki K, Asakawa S, Ito F, Shimizu N (1998) Molecular cloning of a novel putative Ca2 + channel protein (TRPC7) highly expressed in brain. Genomics 54:124-131. CrossRef Medline

Nestler EJ, Hyman SE (2010) Animal models of neuropsychiatric disorders. Nat Neurosci 13:1161-1169. CrossRef Medline

Nicot A, Otto T, Brabet P, Dicicco-Bloom EM (2004) Altered social behavior in pituitary adenylate cyclase-activating polypeptide type I receptordeficient mice. J Neurosci 24:8786-8795. CrossRef Medline

O’Brien WT, Harper AD, Jové F, Woodgett JR, Maretto S, Piccolo S, Klein PS (2004) Glycogen synthase kinase- $3 \beta$ haploinsufficiency mimics the behavioral and molecular effects of lithium. J Neurosci 24:6791-6798. CrossRef Medline

O'Donnell KC, Gould TD (2007) The behavioral actions of lithium in rodent models: leads to develop novel therapeutics. Neurosci Biobehav Rev 31:932-962. CrossRef Medline

Ortiz-Domínguez A, Hernández ME, Berlanga C, Gutiérrez-Mora D, Moreno J, Heinze G, Pavón L (2007) Immune variations in bipolar disorder: phasic differences. Bipolar Disord 9:596-602. CrossRef Medline

Özerdem A, Güntekin B, Atagün I, Turp B, Başar E (2011) Reduced long distance $\gamma(28-48 \mathrm{~Hz})$ coherence in euthymic patients with bipolar disorder. J Affect Disord 132:325-332. CrossRef Medline

Pandey GN, Ren X, Rizavi HS, Dwivedi Y (2010) Glycogen synthase kinase- $3 \beta$ in the platelets of patients with mood disorders: effect of treatment. J Psychiatr Res 44:143-148. CrossRef Medline

Polter A, Beurel E, Yang S, Garner R, Song L, Miller CA, Sweatt JD, McMahon L, Bartolucci AA, Li X, Jope RS (2010) Deficiency in the inhibitory serine-phosphorylation of glycogen synthase kinase-3 increases sensitivity to mood disturbances. Neuropsychopharmacology 35:1761-1774. Medline

Regenold WT, Thapar RK, Marano C, Gavirneni S, Kondapavuluru PV (2002) Increased prevalence of type 2 diabetes mellitus among psychiatric inpatients with bipolar I affective and schizoaffective disorders independent of psychotropic drug use. J Affect Disord 70:19-26. CrossRef Medline

Riboni L, Prinetti A, Bassi R, Caminiti A, Tettamanti G (1995) A mediator role of ceramide in the regulation of neuroblastoma Neuro2a cell differentiation. J Biol Chem 270:26868-26875. CrossRef Medline

Richman JS, Moorman JR (2000) Physiological time-series analysis using 
approximate entropy and sample entropy. Am J Physiol Heart Circ Physiol 278:H2039-H2049. Medline

Ryves WJ, Harwood AJ (2001) Lithium inhibits glycogen synthase kinase-3 by competition for magnesium. Biochem Biophys Res Commun 280: 720-725. CrossRef Medline

Silverman JL, Yang M, Lord C, Crawley JN (2010) Behavioural phenotyping assays for mouse models of autism. Nat Rev Neurosci 11:490-502. CrossRef Medline

Stambolic V, Ruel L, Woodgett JR (1996) Lithium inhibits glycogen synthase kinase-3 activity and mimics wingless signalling in intact cells. Curr Biol 6:1664-1668. CrossRef Medline

Stamos JL, Weis WI (2013) The $\beta$-catenin destruction complex. Cold Spring Harb Perspect Biol 5:a007898. CrossRef Medline

Straub RE, Lehner T, Luo Y, Loth JE, Shao W, Sharpe L, Alexander JR, Das K, Simon R, Fieve RR (1994) A possible vulnerability locus for bipolar affective disorder on chromosome 21q22.3. Nat Genet 8:291-296. CrossRef Medline

Takao K, Miyakawa T (2006) Light/dark transition test for mice. J Vis Exp 1:104. CrossRef Medline

Tang H, Shen N, Jin H, Liu D, Miao X, Zhu LQ (2013) GSK-3 $\beta$ polymorphism discriminates bipolar disorder and schizophrenia: a systematic meta-analysis. Mol Neurobiol 48:404-411. CrossRef Medline

Togashi K, Hara Y, Tominaga T, Higashi T, Konishi Y, Mori Y, Tominaga M (2006) TRPM2 activation by cyclic ADP-ribose at body temperature is involved in insulin secretion. EMBO J 25:1804-1815. CrossRef Medline
Torrent C, Martinez-Arán A, del Mar Bonnin C, Reinares M, Daban C, Solé B, Rosa AR, Tabarés-Seisdedos R, Popovic D, Salamero M, Vieta E (2012) Long-term outcome of cognitive impairment in bipolar disorder. J Clin Psychiatry 73:e899-e905. CrossRef Medline

Undurraga J, Baldessarini RJ, Valenti M, Pacchiarotti I, Vieta E (2012) Suicidal risk factors in bipolar I and II disorder patients. J Clin Psychiatry 73:778-782. CrossRef Medline

Walz JC, Magalhães PV, Reckziegel R, Costanzi M, Giglio L, Kapczinski F (2013) Daytime sleepiness, sleep disturbance and functioning impairment in bipolar disorder. Acta Neuropsychiatr 25:101-104. CrossRef Medline

Xu CM, Wang J, Wu P, Xue YX, Zhu WL, Li QQ, Zhai HF, Shi J, Lu L (2011) Glycogen synthase kinase $3 \beta$ in the nucleus accumbens core is critical for methamphetamine-induced behavioral sensitization. J Neurochem 118: 126-139. CrossRef Medline

Xu C, Li PP, Cooke RG, Parikh SV, Wang K, Kennedy JL, Warsh JJ (2009) TRPM2 variants and bipolar disorder risk: confirmation in a family-based association study. Bipolar Disord 11:1-10. Medline

Yamamoto S, Shimizu S, Kiyonaka S, Takahashi N, Wajima T, Hara Y, Negoro T, Hiroi T, Kiuchi Y, Okada T, Kaneko S, Lange I, Fleig A, Penner R, Nishi M, Takeshima H, Mori Y (2008) TRPM2-mediated Ca2+influx induces chemokine production in monocytes that aggravates inflammatory neutrophil infiltration. Nat Med 14:738-747. CrossRef Medline

Young AH, Newham JI (2006) Lithium in maintenance therapy for bipolar disorder. J Psychopharmacol 20:17-22. CrossRef Medline 